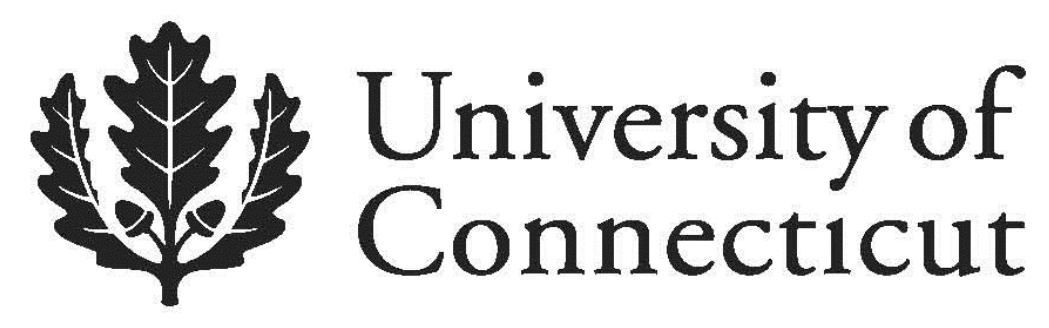

Department of Economics Working Paper Series

\title{
Exchange Rates, Borrowing Costs and Exports: Firm-Level Evidence
}

Kwan Yong Lee

University of North Dakota

Kanda Naknoi

University of Connecticut

Working Paper 2014-18

July 2014

365 Fairfield Way, Unit 1063

Storrs, CT 06269-1063

Phone: (860) 486-3022

Fax: (860) 486-4463

http://www.econ.uconn.edu/

This working paper is indexed on RePEc, http://repec.org 


\title{
Exchange Rates, Borrowing Costs and
}

\section{Exports: Firm-Level Evidence*}

\author{
Kwan Yong Lee ${ }^{\dagger}$ \\ University of North Dakota
}

Kanda Naknoi

University of Connecticut

July 2014

\begin{abstract}
This study empirically examines the effects of currency depreciation on the exporting firms' borrowing costs and exports. Using Korean data, first we find novel evidence that unanticipated currency depreciation increases the firm-level real interest rate for firms in sectors importing intermediate inputs. Next, we show that currency depreciation has contractionary effects of rising costs of borrowing and imported inputs, and an expansionary effect of an improvement in price competitiveness. The overall effect of currency depreciation on exports is found to be contractionary, and our estimation has captured the effects of large financial shocks during financial crises.
\end{abstract}

JEL Classification: F14; F31; F41

Keywords: Balance sheet effect; Exchange rate; Borrowing Costs; Exports

${ }^{*}$ We thank Jungmin Cho, David Hummels, Chang Heon Kim, Volodymr Lugovskyy, Laura Puzzello, and the participants in the 2014 CEA and EEA Annual Meeting for their comments. All errors are our own.

†Department of Economics, University of North Dakota, 293 Centennial Drive Stop 8369, ND 58202-8369; Email: kwanyong.lee@business.und.edu

${ }^{\ddagger}$ Department of Economics, University of Connecticut, 365 Fairfield Way, Unit 1063, Storrs, CT 06269-1063; Email: kanda.naknoi@uconn.edu. 


\section{Introduction}

There is a growing literature that empirically examines the negative effects of borrowing costs on exports (Besedes, Kim and Lugovskyy, 2014; and Chor and Manova 2012). This literature relies on country-level interest rate and sector-level characteristics, suggesting that they do not account for heterogeneity in firm-level borrowing costs. Recently, Feenstra, Li and $\mathrm{Yu}$ (2014) have made an attempt to account for heterogeneity in firm-level interest payments. Still, this literature ignores the impact of exchange rate depreciation on borrowing costs, despite the evidence that in many countries financial crises deepened after currency crises (Kaminsky and Reinhart, 1999). We fill the gap in the literature by providing the first evidence that unexpected currency depreciation raises the exporting firms' borrowing costs. Furthermore, we find that currency depreciation has contractionary effects on firm-level exports.

In particular, we incorporate default risk and imported intermediate inputs into a trade model with differentiated products. Our idea is that the real value of imported intermediate inputs affects the real interest rate faced by exporting firms. This is because they finance imports by borrowing and they may default on loans, as in the trade finance literature. ${ }^{1}$ Moreover, we argue that unexpected currency depreciation increases the exporting firms' default risk by increasing the burden of foreign borrowing. Our argument is in line with the balance sheet effect of currency depreciation in Cespedes, Chang and Velasco (2004). Furthermore, the capital structure literature, such as Hackbarth, Miao and Morellec (2006) and Morellec (2001), suggests that a firm's credit risk depends on its debt and liquidity. Hence, we take into account these factors as additional determinants of the firm-level real interest rate.

\footnotetext{
${ }^{1}$ See Amiti and Weinstein (2011), for example.
} 
Our framework is motivated by the evidence related to trade in intermediate inputs. Specifically, Hummels, Ishii and Yi (2001) find that imported inputs embodied in exported goods account for as much as one-fifth of exports. Recently, Amiti, Itskhoki and Konings (2014) have found that large exporters are also large importers. They demonstrate that exporting firms change sources of imported inputs in response to exchange rate movements to reduce the effects of exchange rate on costs. However, we abstract from the choice of sources of inputs, as in Amiti et al. (2014), and the decision to begin exporting, as in Melitz (2003), to focus on the adjustment of exporting firms along the intensive margin.

There are three main predictions. First, an unexpected depreciation of the real exchange rate (RER) against the currency of foreign debt raises the real interest rate for firms importing intermediate inputs, as import finance carries default risk. The rising real interest rate hurts the firm's balance sheet and exports. This balance sheet channel is captured by the interaction of unexpected RER depreciation with the one-period lagged sector-specific real imports of intermediate inputs (RIIM). Second, a depreciation against the currency of source countries reduces exports, because it raises the costs of imported intermediate inputs. This input costs channel is captured by the sector-specific import-share weighted multilateral RER (MRER). Finally, a depreciation against the currency of exporting destinations raises exports by reducing the buyer's price. This competitiveness channel is captured by the sector-specific export-share weighted multilateral RER (XRER).

Next, we test our predictions using data on 420 Korean exporting firms in 13 sectors from 1991 to 2009. We exploit both cross-sectional and time-series variations of RERs, RIIM and risk measures to identify channels through which they influence exporting firms. To this end, 
we construct a measure for firm-level real interest rate as the ratio of interest expenditure to the average debt of the current year and the previous year, adjusted by Korea's inflation. Other measures we constructed are the firm-level credit risk and liquidity risk; sector-level RIIM, MRERs and XRERs; and country-level unexpected RER depreciation and credit risk.

The empirical results strongly support our predictions. Quantitatively, a $1 \%$ unexpected RER depreciation and one standard deviation increase in lagged RIIM would raise the firmlevel real interest rate by $0.195 \%$. Given the actual $60 \%$ won-dollar RER depreciation rate in 1997, the implied balance sheet effect of the won crisis could increase the real interest rate for firms of which lagged RIIM is one standard deviation higher than for other firms by as much as $11.70 \%$. This balance sheet effect on the firm-level real interest rate is substantial.

As for the balance sheet effect on exports, a $1 \%$ unexpected RER depreciation and one standard deviation increase in RIIM reduces exports by 3.90\%. The predicted balance sheet effect is much larger than those in the existing literature, such as Bleakley and Cowan (2008) and Kim, Zhang and Tesar (2012). Through the intermediate inputs channel, a 1\% depreciation in the MRER reduces exports by $0.96-1.13 \%$. Through the competitiveness channel, a $1 \%$ depreciation in the XRER raises exports by $0.41-0.52 \%$. Overall, depreciation has a contractionary effect on exports, and the impact of $1 \%$ depreciation conditioning on one standard deviation increase in RIIM ranges from $-4.5 \%$ to $-5.4 \%$ depending on the specification.

As for the impact of firm-level risk other than currency risk, a $1 \%$ rise in the ratio of debt to sales raises the firm-level real interest rate by $0.7 \%$ and reduces exports by $0.2 \%$. However, a $1 \%$ rise in the ratio of cash flow to sales or the ratio of trade credit to sales raises exports by $0.5 \%$ without statistically significant effects on the real interest rate. For the macro variables, a 
$1 \%$ rise in the US real interest rate is found to raise the firm-level real interest rate by $1 \%$ and reduce exports by $2.5 \%$. A rise in Korea's credit risk is found to raise the firm-level real interest rate and reduce exports, but we cannot infer the quantitative impact since Korea's credit risk is a ranking.

In addition, we examine the effects of the Asian financial crisis and the US financial crisis using dummy variables. Based on the examination, we find that financial crises do not have significant effects on firm-level exports. This result implies that variation of our determinants of firm-level real interest rate has sufficiently captured the effects of financial shocks.

We make contributions to three strands of literature. First, our results lend support to the literature on contractionary devaluations (Edwards, 1986; Cespedes, et al. 2004). The crucial point is that we find that contractionary devaluations operate through both the imported inputs channel and the balance sheet channel. Consequently, even if 100\% of loans are denominated in local currency, devaluations will still be contractionary as long as the structure of trade in intermediate inputs remains unchanged. Thus, in addition to policies that promote the localcurrency bond market, policies that reduce the costs of intermediate inputs are critical for alleviating the contractionary effect of devaluations. Examples of such policies are a reduction in tariffs and tax incentives for exporting firms that heavily rely on imported intermediate inputs.

Second, we uncovered strong evidence for the balance sheet effect of currency depreciation, contrary to the weak evidence in the literature. The existing studies, such as Bleakley and Cowan (2008), Kesriyeli, Ozmen, and Yigita (2011), and Kim, et al. (2012), identify the balance sheet effect of currency depreciation using variation in foreign debts. Although we 
do not observe foreign debts in our data set, we exploit variation in the RIIM and firm-level interest rate instead.

Finally, we contribute to the trade finance literature by providing evidence related to the causes and effects of heterogeneity in the exporting firms' interest rate. In closely related work, Besedes et al. (2014) and Chor and Manova (2012) examine the effects of a countryspecific interest rate multiplied with the sector-specific and time-variant degree of external finance dependence on exports. In addition, their estimated effects do not have a quantitative implication, because they provide no mapping from their degree of external finance dependence to the scale of interest rate. Moreover, our work is complementary to Amiti and Weinstein (2011) since they estimate the effects of the quantity of loans on exports, whereas we focus on the effects of the cost of loans on exports. Feenstra et al. (2014) find that the firm-specific interest payment has a negative and significant impact on sales, but they neither account for currency risk nor examine determinants of the firm-level real interest rate.

The remaining sections of our study are organized as follows. Section 2, conceptually and empirically, shows the determinants of the firm-level real interest rate. In Section 3, we present theory related to the impact of exchange rates and financial risks on firm-level export. We conclude in Section 4.

\section{Determinants of Firm-Level Real Interest Rate}

In this section, we decompose the firm-level real interest rate into the risk-free rate, the expected RER depreciation, the country-level risk, the sector-level risk and the firm-level of risk. Our primary focus is the risk associated with the exchange rate between the exporting firm's 
country and the currency denomination of foreign borrowing. Following the decomposition, we discuss our data set and the empirical evidence.

\subsection{Decomposition of Firm-Level Real Interest Rate}

Let us assume free capital mobility. Therefore, firms can borrow from both domestic and world capital markets at the same interest rate adjusted with the expected RER depreciation. Let $r_{f i, t+1}$ denote the real interest rate on loans extended to firm $f$ in country $i$ from period $t$ to period $t+1$. In the presence of country-specific credit risk and firm-specific risk, firms pay the country's and firm's credit spreads in addition to the risk-free real interest rate:

$$
r_{f i, t+1}=r_{u s, t+1}+\Delta \ln \left(R E R_{i, u s, t+1}^{e}\right)+\lambda_{i, t+1}+\rho_{1 f, t+1}+\rho_{2 f, t+1}
$$

where $r_{u s, t+1}$ is the real interest rate on the risk-free bond, which is assumed to be the United States government bond. $\Delta \ln \left(R E R_{i, u s, t+1}^{e}\right)$ is the expected change in logarithm of country $i$ US bilateral RER. Note that the actual country $i$-US RER is defined without superscript $e$ as $R E R_{i, u s, t}=E_{i, u s, t} P_{u s, t} / P_{i t}$, where $E_{i, u s, t}$ is the nominal exchange rate or units of currency $i$ per US dollar, $P_{u s, t}$ is the US CPI and $P_{i, t}$ country $i$ 's CPI. ${ }^{2}$ The variable $\lambda_{i, t+1}$ denotes the country's credit spread. The firms' credit spread has two components: currency risk premium or $\rho_{1 f, t+1}$; and non-currency risk premium or $\rho_{2 f, t+1}$.

\footnotetext{
${ }^{2}$ The risk-free real interest rate in terms of country $i$ 's consumption basket is the sum of the US real interest rate from period $t$ to period $t+1\left(r_{u s, t+1}\right)$ and the expected future RER between country $i$ and the US $\left(\Delta \ln \left(R E R_{i, u s, t+1}^{e}\right)\right)$. To see why, suppose the risk-free nominal interest rate is $i_{u s, t+1}$. Borrowing $\$ 1$ in period $t$ is equivalent to borrowing $E_{i, u s, t} / P_{i t}$ units of country $i$ 's consumption basket. At the end of maturity, the payment including principal in terms of country $i$ 's consumption basket is $\left(1+i_{u s, t+1}\right) E_{i, u s, t+1}^{e} / P_{i, t+1}^{e}$, where the superscript $e$ denotes the expectation of the end-of-period variables. Then, the risk-free real interest rate $r_{t+1}^{\star}=$ $\ln \left(\left(1+i_{u s, t+1}\right)\left(E_{i, u s, t+1}^{e} P_{i t}\right) /\left(E_{i, u s, t} P_{i, t+1}^{e}\right)\right)$. Thus, $r_{t+1}^{\star}=\ln \left(\left(1+i_{u s, t+1}\right)\left(E_{i, u s, t+1}^{e} P_{i t}\right) /\left(E_{i, u s, t} P_{i, t+1}^{e}\right)\right)+$ $\ln \left(P_{u s, t+1}^{e} / P_{u s, t}\right)-\ln \left(P_{u s, t+1}^{e} / P_{u s, t}\right)$. Rearranging terms gives $r_{t+1}^{\star} \approx r_{u s, t+1}+\Delta \ln \left(R E R_{i, u s, t+1}^{e}\right)$, where $r_{u s, t+1}=i_{u s, t}-\ln \left(P_{u s, t+1}^{e} / P_{u s, t}\right)$
} 
Our primary interest is in the currency risk premium, which measures the compensation for risk associated with unexpected currency depreciation against the currency of foreign borrowing. In general, firms are affected by unexpected currency depreciation through the foreign currency exposure of costs and revenues. Our main idea is that borrowing to finance imported intermediate inputs is a new channel of exposure to currency risk that has not been considered in the literature. As documented by Hummels et al. (2001) and Amiti et al. (2014), exporters are also importers buying intermediate inputs from a large number of countries. Thus, the currency composition of import finance influences the cost of servicing debt. Provided that the exporting firms do not hedge their currency exposure using instruments in forward or future markets, unanticipated RER depreciation raises the real value of foreign-currency debts and thus increases the firm's default risk.

To be specific, we consider the following empirical counterpart of equation (1):

$$
\begin{aligned}
r_{f i t}= & \eta_{0}+\eta_{1} r_{u s, t}+\eta_{2} \Delta \ln \left(R E R_{i, u s, t}^{e}\right)+\eta_{3} \tilde{\lambda}_{i t}+\eta_{4} \Delta \ln \left(R E R_{i, u s, t}^{u}\right) \ln \left(R I I M_{s i, t-1}\right) \\
& +\eta_{5} \tilde{\rho}_{2 f i t}+u_{f i t},
\end{aligned}
$$

where $\tilde{\lambda}_{i t}$ is proxy for country risk, $\Delta \ln \left(R E R_{i, u s, t}^{u}\right)$ is unexpected RER depreciation, $R I I M_{s i, t-1}$ is the one-period lagged sector-level RIIM, $\tilde{\rho}_{2 f i t}$ is a proxy for a firm's credit risk unrelated to unexpected RER depreciation, and $u_{f i t}$ is the error term.

Our proposed channel of risk is built on the trade finance literature. Defaults by importers typically influence the exporters' default risk, because exporters use the letter of credit from banks lending to importers as collateral to borrow working capital. (See Amiti and Weinstein (2011), for example.) If importers default, then the collateral value of the letter of credit will 
plunge and that will raise exporters' default risk. However, our proposed channel of risk affects the exporters through their risk of default on loans financing their own imports, because they are simultaneously importers. Of course, they are also exposed to other types of default risk unrelated to the financing of their own imports.

In the liability dollarization literature, unexpected RER depreciation theoretically increases the cost of servicing foreign debt (Cespedes et al., 2004). This is called the balance sheet effect, as it reduces the firm's net worth. Empirically, Aguiar (2005) finds that RER depreciation reduces investment by firms carrying dollar debt, but he does not differentiate between expected and unexpected RER depreciation as we do in (2). Bleakley and Cowan (2008) differentiate the two types of RER depreciation, but they do not find that unexpected RER depreciation has a significant impact on investment. Their result may be affected by measurement errors in their measure of unexpected RER depreciation. Although they provide weak evidence that actual RER depreciation raises interest expenditures for firms carrying dollar debts, they do not estimate the impact of unexpected RER depreciation on the firm-level interest rate as in (2).

\subsection{Firm-Level Real Interest Rate and Financial Risks: Data}

Our data are from the Korea Fair Trade Commission Database. The database provides annual firm-level data for firms listed on Korea's Stock Exchange and covers a large number of financial variables. Our data set covers 420 firms over the years 1991-2009, therefore it allows us to investigate the role of the 1997 Asian financial crisis and the 2008 US financial crisis. We use the following financial variables from the database: account receivables, account payables, 
cash flow from operation, debt, exports, interest expenditures, number of employees, wages, and sales (i.e. exports plus domestic sales). To maximize the sample size, we use an unbalanced panel.

We construct the firm-level nominal interest rate as the ratio of interest expenditure to average debt outstanding for the previous period and the current period. Then, we obtain the firm-level real interest rate by subtracting Korea's consumer price index (CPI) inflation rate from the firm-level nominal interest rate. Hence,

$$
r_{f i t}=\frac{\text { Interest Expenditure }_{f i t}}{0.5\left(\text { Debt }_{f i t}+\text { Debt }_{f i, t-1}\right)}-\text { Inflation }_{i t} .
$$

Korea's CPI series are from the International Monetary Fund's International Financial Statistics (IFS). We drop the top $1 \%$ of firms' real interest rate from our sample to remove outliers. Only two firms in our data set pay a negative real interest rate on average. For the rest, the average real interest rate over all years ranges from $0.5 \%$ to $17.5 \%$.

The time-series of average firm-level real interest rates across firms is depicted in Figure 1. There was a huge spike after the Asian Crisis. Korea's currency crisis started in October 1997, and it took a year for the average borrowing costs to rise. In fact, from 1997 to 1998, the average and the median real interest rate fell slightly. Since some firms defaulted during this period, their interest expenditures declined and on average the borrowing cost appeared to fall in 1998. In 1999, compared to 1998, the average real interest rate increased 3.3\%. After that the average real interest rate continuously decreased, but started increasing in 2005. From 2006 to 2008 it fell and subsequently went up after the US financial crisis in 2008. 
Figure 1: Average of real interest rate over all firms

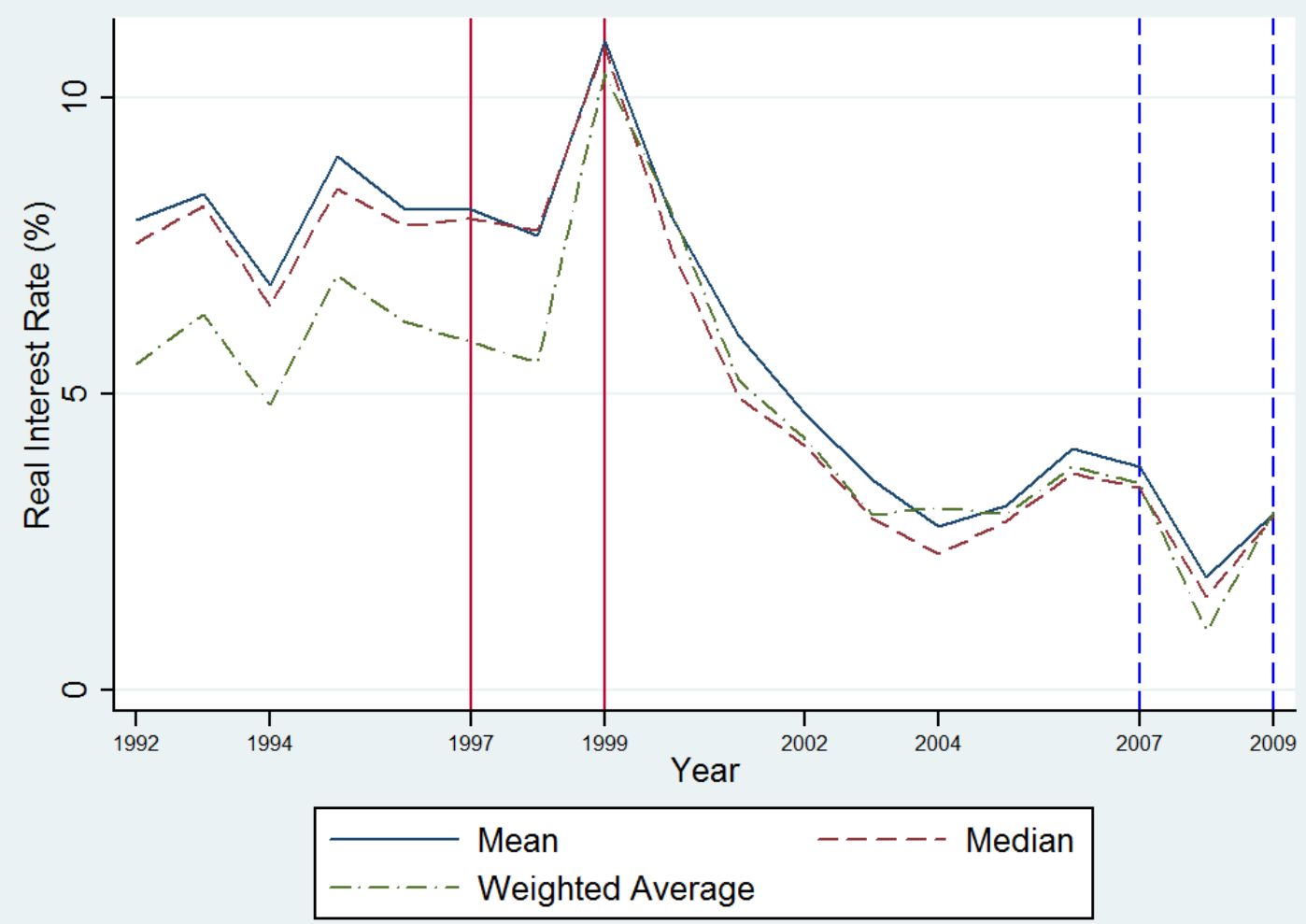

Note: Firm-level real interest rate $(\mathrm{t})=($ interest expenditure $(\mathrm{t}) /(0.5(\operatorname{debt}(\mathrm{t}-1)+\operatorname{debt}(\mathrm{t}))$ inflation(t))100. The weight used to construct the weighted average is the share of firm's total sales in the sum of total sales over all firms.

For the unexpected RER depreciation from year $t-1$ to year $t$, we calculate it as the deviation of actual RER depreciation from its expectation, which is obtained using the forward exchange rate and the spot exchange rate:

$$
\begin{aligned}
& \Delta \ln \left(R E R_{i, u s, t}^{u}\right)=\Delta \ln \left(R E R_{i, u s, t}\right)-\Delta \ln \left(R E R_{i, u s, t}^{e}\right) \\
& \Delta \ln \left(R E R_{i, u s, t}^{e}\right)=\ln \left(F_{i, u s, t-1}\right)-\ln \left(E_{i, u s, t-1}\right)-\left(\Delta \ln \left(P_{u s, t}\right)-\Delta \ln \left(P_{i, t}\right)\right),
\end{aligned}
$$

where $F_{i, u s, t-1}$ is the one-year won-dollar non-deliverable forward exchange rate quoted in the end of year $t-1$ from the Bloomberg database. The spot exchange rate and CPI data are from 
the IFS. The forward rate is available from the year 1998. Before 1998, the forward market for the won-dollar exchange rate did not exist, because Korea maintained a rigidly fixed exchange rate regime for a long time until the currency crisis in late 1997. For this reason, we assume that $\ln \left(F_{i, u s, t}\right)-\ln \left(E_{i, u s, t}\right)=0$ for $t<1998$.

Figure 2: Won-dollar real exchange rate depreciation rate

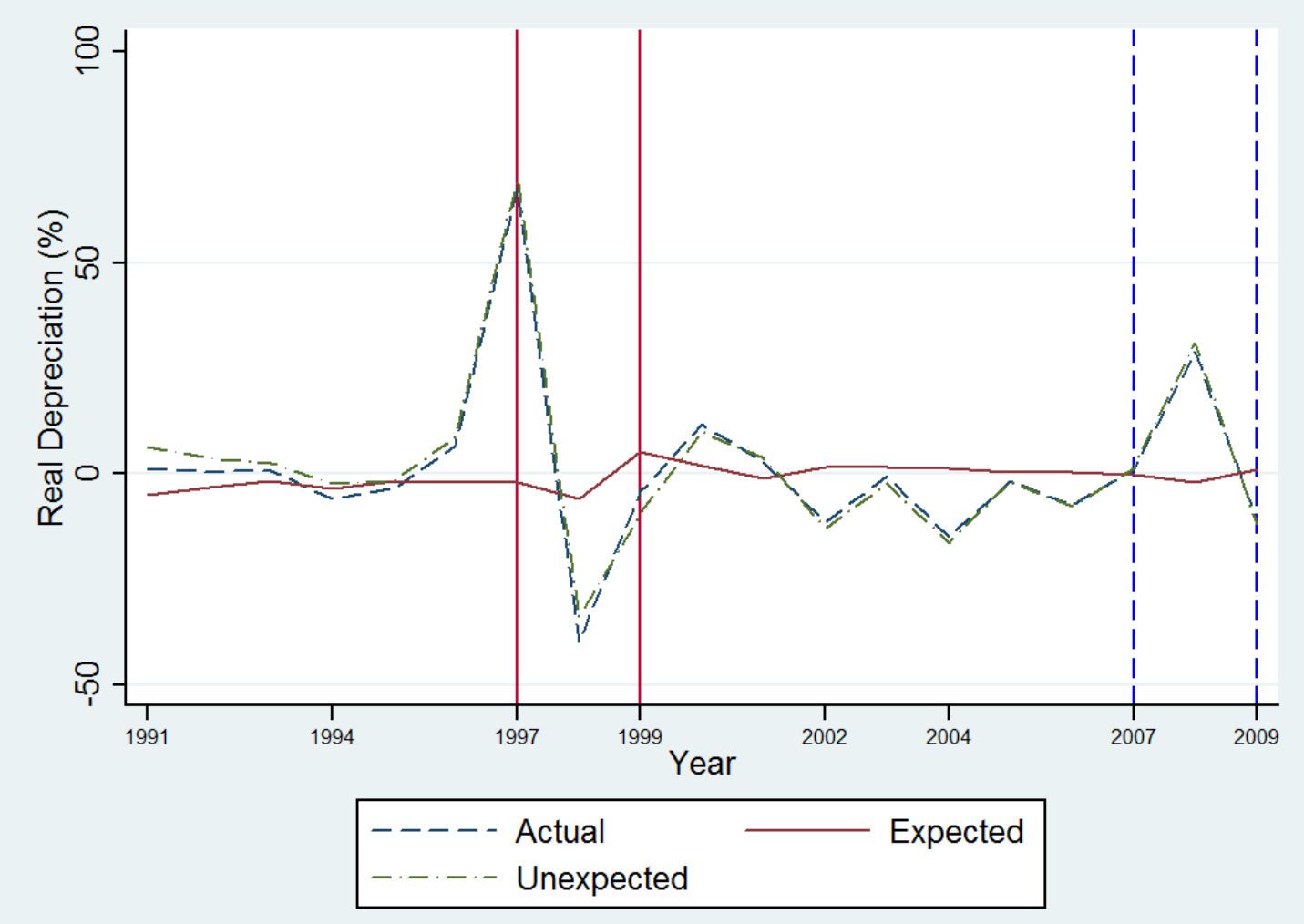

We plot actual, expected and unexpected RER depreciation over time in Figure 2. Actual and unexpected depreciation track each other closely, with $96 \%$ correlation. In contrast, expected RER depreciation is negatively correlated with unexpected RER depreciation with $-34 \%$ correlation. There were two major spikes in actual RER depreciation and unexpected RER depreciation: over 60\% depreciation during the Asian financial crisis in 1997 and almost $30 \%$ depreciation during the US financial crisis in 2008. Nonetheless, the post-crisis correction 
was much larger in 1998 than 2009. In 1998, the won appreciated 40\%, whereas its appreciation in 2009 was 10\%. In regular years, the rate of depreciation for the won fluctuates within $+/-18 \%$, a considerably wide range. This extreme time-series variation is especially useful for identifying the balance sheet effect.

We interact unanticipated RER depreciation with sector-level lagged real imports of intermediate inputs, which is the lagged nominal value of imported intermediate inputs from the Bank of Korea's input-output table deflated by lagged CPI. We use sector-level imports of intermediate inputs, because firm-level data are not available. For this purpose, we classify firms into 13 industries in the input-output table, as classified by the Bank of Korea.

Figures $3 \mathrm{a}$ and $3 \mathrm{~b}$ show cross-sectional variation and time-series variation of imports of intermediate inputs. There is wide variation of imports of intermediate inputs across sectors and time. Although it has an upward trend, it declined before the Asian financial crisis and gradually rose after that. However, its movement before and after the US financial crisis was the opposite.

As for credit risk not associated with currency risk, the literature on capital structure argues that leverage is an important determinant of credit spread. (See Hackbarth et al. (2006), for example.) In addition, Morellec (2001) illustrates that liquidity helps explain leverage and credit spread. Recently, there is empirical evidence supporting the importance of liquidity for exporting firms. Love, Preve, and Sarria-Allende (2007) find that trade credit collapsed during and shortly after financial crises. Therefore, we consider three proxies with one-period lag: debt to sales, cash flow to sales and net trade credit to sales. These proxies are measured relative to sales, because large firms tend to have large debt, large cash flow and large trade credit. 
We hypothesize that an increase in the ratio of debt to sales increases credit risk, whereas an increase in the ratio of cash flow or trade credit to sales decreases liquidity risk.

Figure 3: Real imports of intermediate inputs, in logarithm

(a) Average of all years

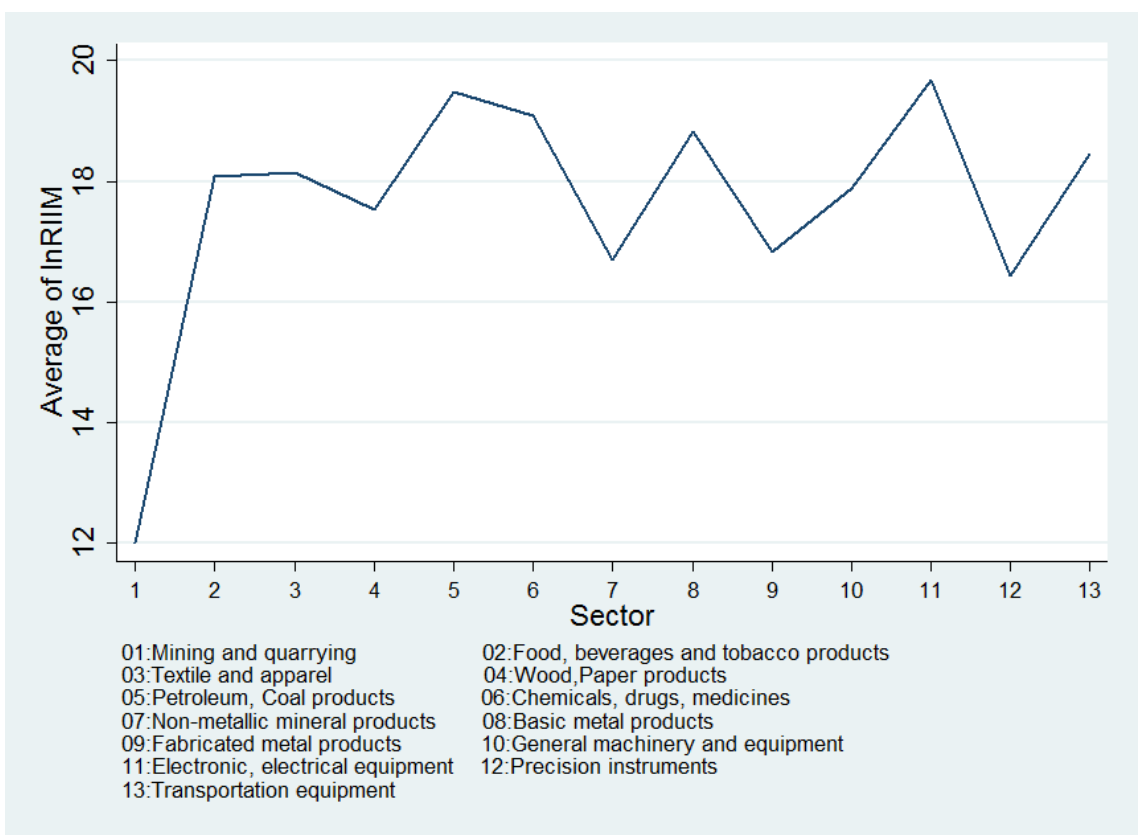

(b) Average of all sectors

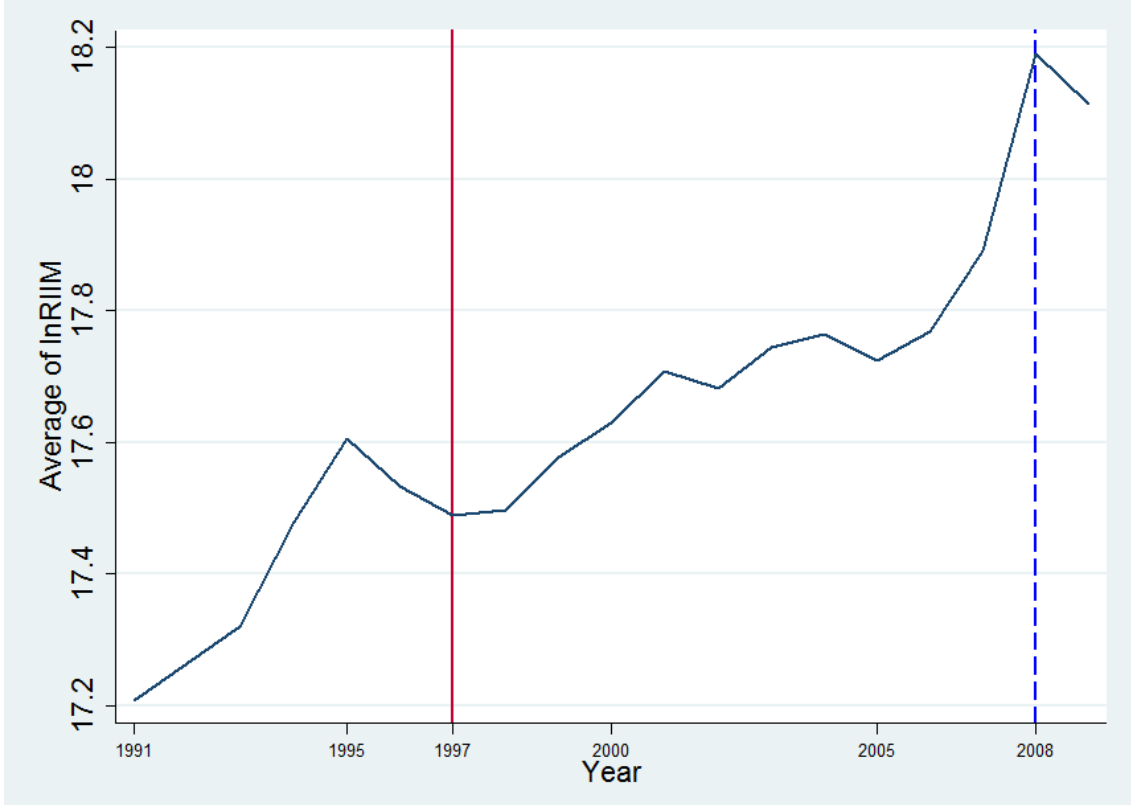


Figure 4: Proxy of firm-level risk

(a) Average of firm's debt relative to sales over all firms

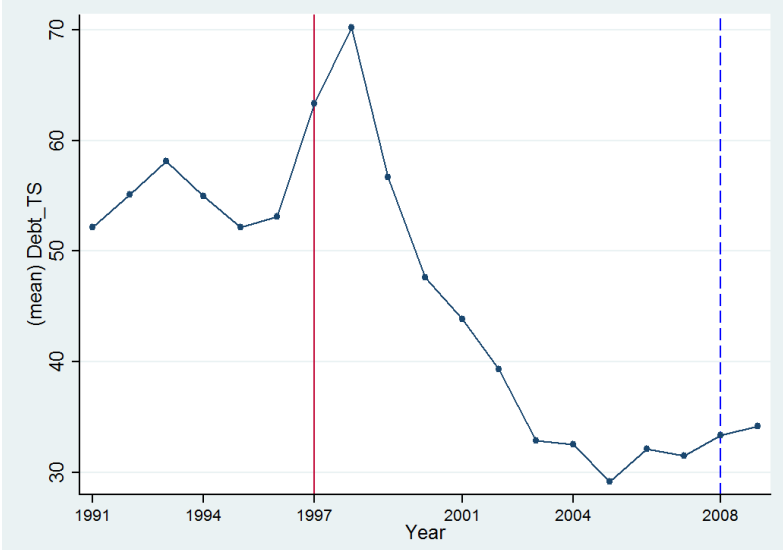

(b) Average of firm's cash flow from operation relative to sales over all firms

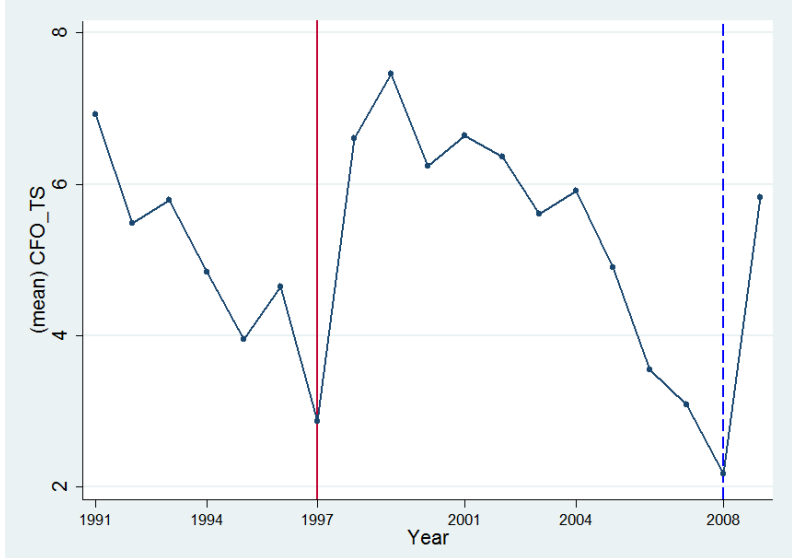

(c) Average of firm's net trade credit relative to sales over all firms

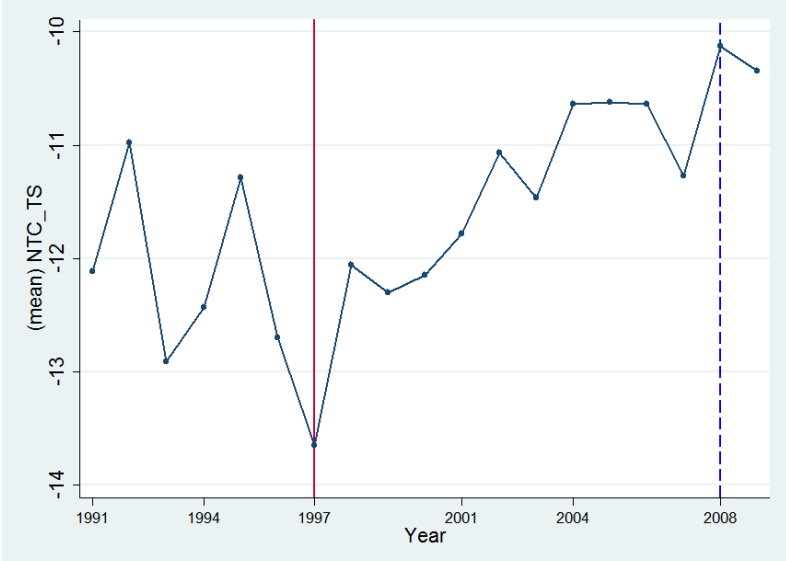


In Figure 4a, the ratio of debt to sales reached its peak in 1998, one year after the Asian financial crisis. The post-crisis increase was due to a sharp rise in the debt burden following large-scale depreciation of the won. After that, the debt to sales ratio declined and was not much affected by the US financial crisis. In contrast, the ratio of cash flow to sales and the ratio of net trade credit to sales in Figures $4 \mathrm{~b}$ and $4 \mathrm{c}$ plunged in the Asian financial crisis year. This pattern is consistent with the study of trade credit during the Asian crisis by Love et al. (2007). During the US financial crisis in 2008, on average the ratio of cash flow to sales plunged again but the ratio of net trade credit to sales sharply increased. Later the ratio of net trade credit to sales declined after the US financial crisis.

We obtain the US real interest rate by subtracting the US inflation rate from the nominal interest rate on US 5-year treasury securities. The data on the US nominal interest rate are from the Federal Reserve. In Figure 5, the US real interest rate fluctuates over time with a downward trend. It rose before the Asian financial crisis and fell after that until the US financial crisis occurred.

The data of country-level financial risk are from the International Country Risk Guide, which rates financial risk points in the following categories: total foreign debt as a percentage of GDP; debt service as a percentage of exports of goods and services; current account as a percentage of exports of goods and services; international liquidity as months of import cover; and exchange rate instability as a percentage change. A decrease in these financial risk points means rising risk. We calculate Korea's country risk rating as the difference between the total of financial risk points in all categories for the US and that for Korea. Hence, a rise in our measure of Korea's country risk rating means rising risk for Korea relative to the US. This measure of 
country risk is consistent with the notion that the US government bond is the benchmark bond in the international capital market.

Figure 5: Real interest rate on the US government bond

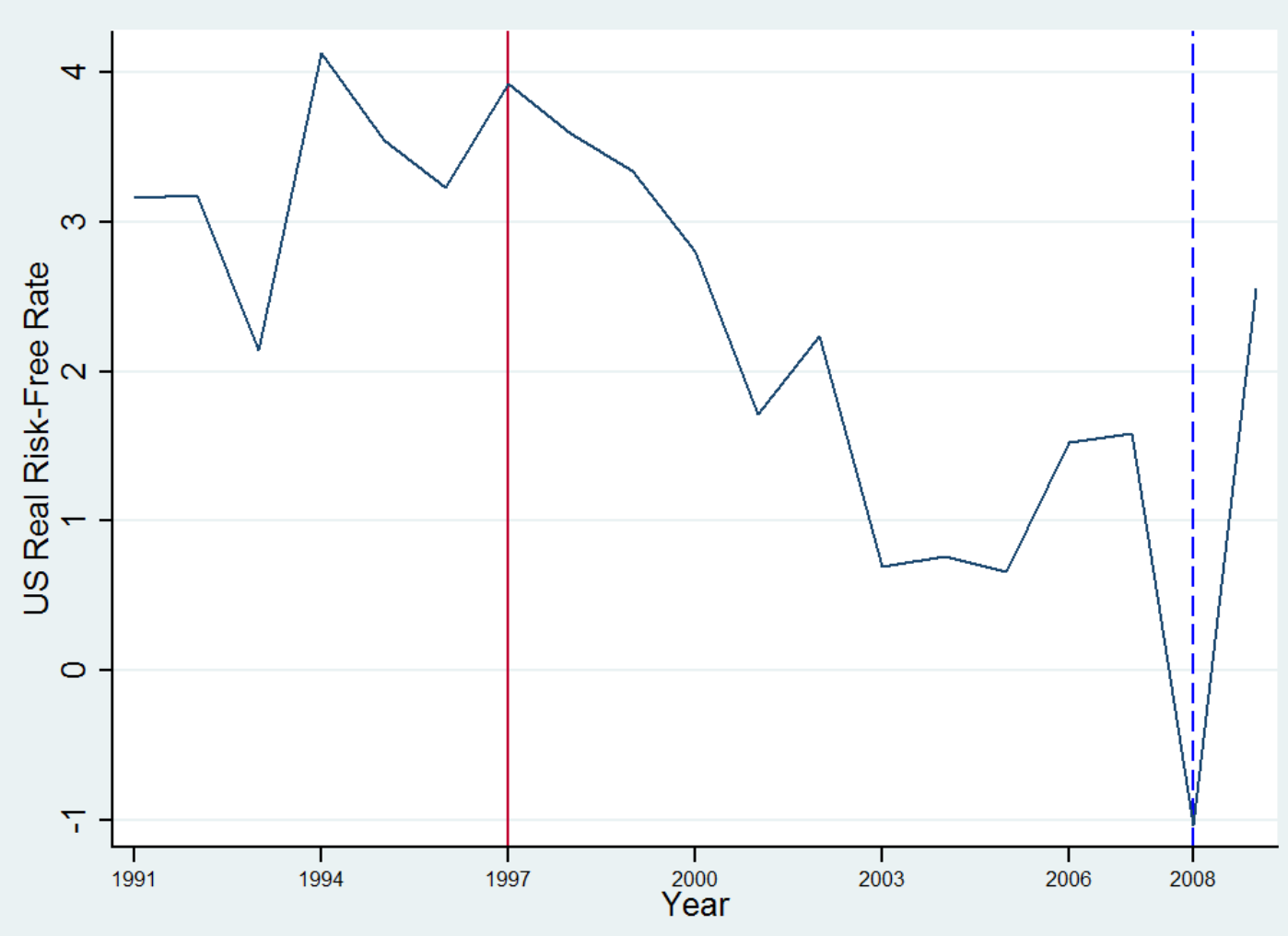

Note: The US government bond is 5-year treasury securities. The real interest rate is the difference between the nominal interest rate and the US inflation rate.

The time series of Korea's credit risk rating are in Figure 6. There were two major spikes in Korea's country risk, in 1998 and in 2008. Both spikes resulted from the spillover of the financial crises. The level of country risk rating indicates that before the Asian financial crisis Korea had lower country risk than the US. After the Asian crisis, in 1999 Korea's country risk continued a downward trend until 2007, although there was a small increase in 2001. As a consistency check, we compare our measure of Korea's country risk with the Fitch's sovereign 
rating for Korea. In the years in which the Fitch's sovereign rating deteriorated, our measure of country risk increased, and vice versa. ${ }^{3}$

Figure 6: Korea's Country Risk Rating

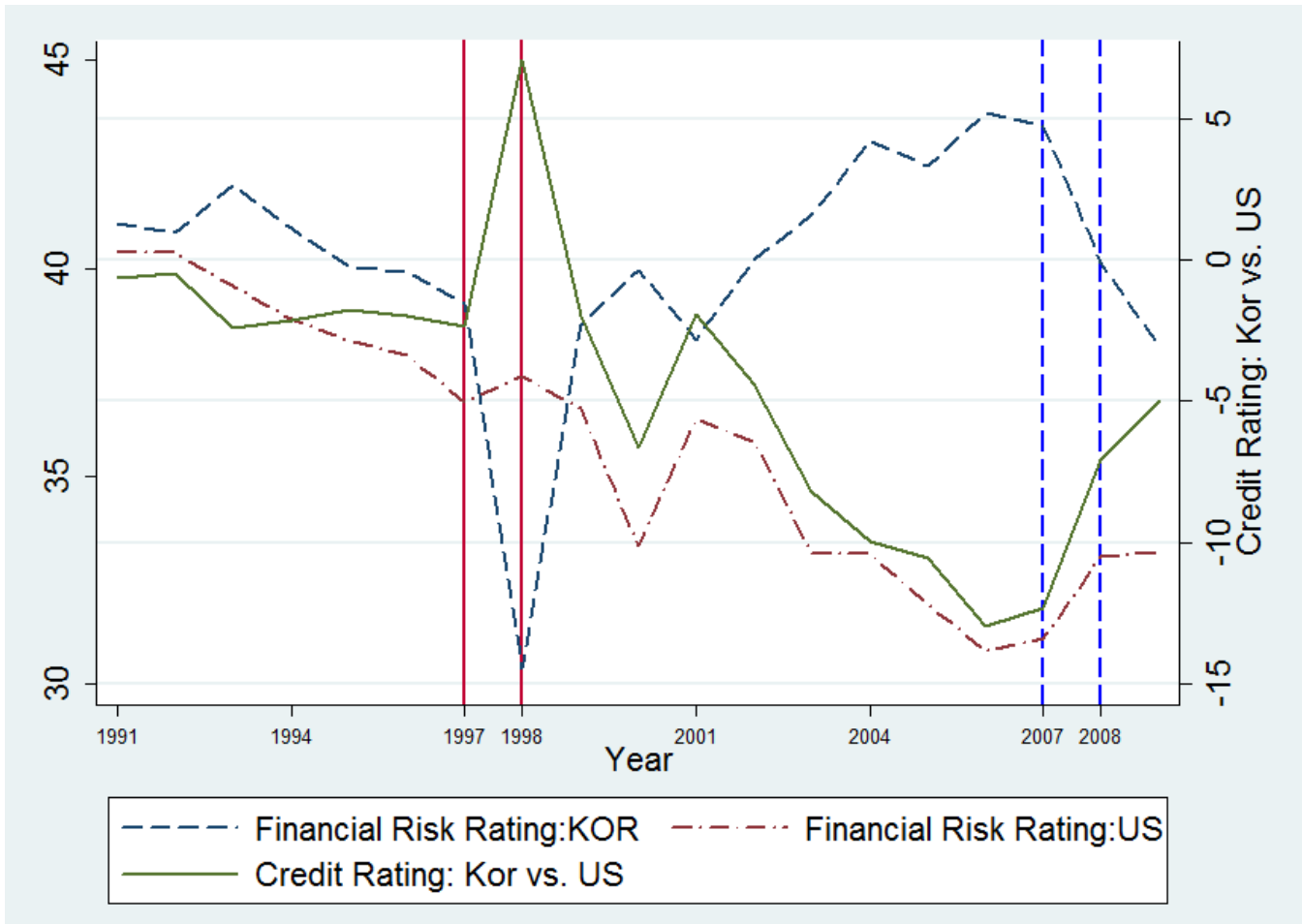

Note: Korea's country risk $=$ The US financial risk rating - Korea's financial risk rating. The financial risk rating is the sum of all financial risk points in all categories from the International Country Risk Guide.

\subsection{Firm-Level Real Interest Rate and Financial Risks: Evidence}

We treat the US real interest rate, won-dollar real exchange rate depreciation rate and country risk rating as exogenous, because it is unlikely that any single firm can influence these macro variables. We estimate equation (2) with and without firm fixed effects. We include the firm fixed effects to mitigate omitted variable bias, because some time-invariant firm-specific

\footnotetext{
${ }^{3}$ Although we can convert the Fitch's sovereign rating into numeric scales, the Fitch's sovereign rating for Korea began in 1996, five years after the first year of our sample periods. For this reason, we do not use the Fitch's sovereign rating in the estimation.
} 
factors may affect the cost of borrowing. For instance, Lee, Lee, and Lee (2000) found that large conglomerates in Korea have easier access to credit than non-conglomerate firms. In light of their finding, it is possible that Korean conglomerates might have paid lower interest rates than non-conglomerate firms. Although Boreinsztein and Lee (2002) found that after the Asian crisis Korean conglomerates do not enjoy easier access to credits than non-conglomerates, other time-invariant firm-specific factors, such as location, may still influence the cost of borrowing.

Table 1 reports the estimated coefficients from equation (2). The results strongly support our proposal that an expected RER depreciation raises the real interest rate for firms in the sectors importing intermediate inputs. Quantitatively, a 1\% unexpected RER depreciation and one standard deviation (195\%) increase in lagged RIIM would raise the firm-level real interest rate by $0.195 \%$. In 1997, the unexpected won-dollar RER depreciation rate increased $60 \%$. Therefore, the implied balance sheet effect of the won crisis could increase the real interest rate for firms of which lagged imports of intermediate inputs is one standard deviation higher than other firms by $10.70 \%$. This magnitude is large.

We can calculate the balance sheet effect on Korean firms' borrowing costs during the US financial crisis in a similar way. In 2008, the won-dollar depreciation rate increased $30 \%$. Thus, the implied balance sheet effect is a $5.35 \%$ increase in the real interest rate for firms of which lagged RIIM is one standard deviation higher than other firms.

As shown in Table 1, all three macro variables have significant and positive impacts on the firm-level real interest rate across all specifications. Moreover, the scale of coefficients is reasonable. A $1 \%$ increase in the US real interest rate raises the firm-level interest rate by roughly $1 \%$, implying that shocks on the US real interest rate are fully transmitted to Korean 
Table 1: Balance sheet effect of currency depreciation - Financing imports

\begin{tabular}{|c|c|c|c|c|c|c|}
\hline $\begin{array}{l}\text { Dependent variable: } \\
\text { Firm-level real interest rate }\end{array}$ & $(1)$ & $(2)$ & $(3)$ & $(4)$ & $(5)$ & $(6)$ \\
\hline US real interest rate & $\begin{array}{l}1.055^{* * *} \\
(0.050)\end{array}$ & $\begin{array}{l}0.988^{* * *} \\
(0.048)\end{array}$ & $\begin{array}{l}1.112^{* * *} \\
(0.047)\end{array}$ & $\begin{array}{l}1.015^{* * *} \\
(0.045)\end{array}$ & $\begin{array}{l}1.112^{* * *} \\
(0.048)\end{array}$ & $\begin{array}{l}1.020^{* * *} \\
(0.045)\end{array}$ \\
\hline Expected $\Delta \ln (\mathrm{RER})$ & $\begin{array}{l}0.336^{* * *} \\
(0.029)\end{array}$ & $\begin{array}{l}0.341^{* * *} \\
(0.027)\end{array}$ & $\begin{array}{l}0.345^{* * *} \\
(0.027)\end{array}$ & $\begin{array}{l}0.351^{* * *} \\
(0.025)\end{array}$ & $\begin{array}{l}0.341^{* * *} \\
(0.028)\end{array}$ & $\begin{array}{l}0.354^{* * *} \\
(0.025)\end{array}$ \\
\hline Country credit risk & $\begin{array}{l}0.237^{* * *} \\
(0.017)\end{array}$ & $\begin{array}{l}0.220^{* * *} \\
(0.016)\end{array}$ & $\begin{array}{l}0.240^{* * *} \\
(0.015)\end{array}$ & $\begin{array}{l}0.232^{* * *} \\
(0.014)\end{array}$ & $\begin{array}{l}0.240^{* * *} \\
(0.016)\end{array}$ & $\begin{array}{l}0.234^{* * *} \\
(0.014)\end{array}$ \\
\hline $\begin{array}{l}\text { Unexpected } \Delta \ln (\text { RER }) \\
\mathrm{x} \ln (\operatorname{RIIM}(-1))\end{array}$ & $\begin{array}{l}0.001^{* * *} \\
(0.000)\end{array}$ & $\begin{array}{l}0.001^{* * *} \\
(0.000)\end{array}$ & $\begin{array}{l}0.001^{* * *} \\
(0.000)\end{array}$ & $\begin{array}{l}0.001^{* * *} \\
(0.000)\end{array}$ & $\begin{array}{l}0.001^{* * *} \\
(0.000)\end{array}$ & $\begin{array}{l}0.001^{* * *} \\
(0.000)\end{array}$ \\
\hline Debt to sales $(-2)$ & $\begin{array}{l}0.007^{* * *} \\
(0.001)\end{array}$ & $\begin{array}{l}0.009 * * * \\
(0.002)\end{array}$ & & & & \\
\hline Cash flow to sales $(-1)$ & & & $\begin{array}{l}-0.027^{* * *} \\
(0.006)\end{array}$ & $\begin{array}{l}-0.006 \\
(0.006)\end{array}$ & & \\
\hline Trade credit to sales $(-1)$ & & & & & $\begin{array}{l}-0.004 \\
(0.004)\end{array}$ & $\begin{array}{l}0.006 \\
(0.010)\end{array}$ \\
\hline Constant & $\begin{array}{l}4.385^{* * *} \\
(0.213)\end{array}$ & $\begin{array}{l}2.194^{* * *} \\
(0.730)\end{array}$ & $\begin{array}{l}4.774^{* * *} \\
(0.183)\end{array}$ & $\begin{array}{l}2.638^{* * *} \\
(0.731)\end{array}$ & $\begin{array}{l}4.582^{* * *} \\
(0.192)\end{array}$ & $\begin{array}{l}2.532^{* * *} \\
(0.737)\end{array}$ \\
\hline Sample size & 4,277 & 4,277 & 4,659 & 4,659 & 4,664 & 4,664 \\
\hline$R^{2}$ & 0.269 & 0.486 & 0.272 & 0.482 & 0.268 & 0.482 \\
\hline Firm FE & No & Yes & No & Yes & No & Yes \\
\hline
\end{tabular}

firms' borrowing costs. The coefficient of expected RER depreciation is significant and much lower than 1. This implies that arbitrages in the forward exchange rate market are costly. Deterioration of credit risk significantly raises the real interest rate, but we cannot make a quantitative interpretation because the country credit risk takes the form of a ranking.

Finally, for firm-level risk, as expected the two-period lagged ratio of debt to sales has a positive and significant effect, with and without firm fixed effects. Quantitatively, a 1\% increase in the lagged ratio of debt to total sales raises the firm-level real interest rate by slightly less 
than $0.01 \%$. The coefficient of lagged ratio of cash flow to sales also has the expected sign, but it is significant only when firm fixed effects are excluded. However, the lagged ratio of trade credit to sales has no significant effect on the firm-level real interest rate.

As a robustness check, we replace the one-period lagged RIIM with two-period lagged real debt (RDEBT), and estimate the balance sheet effect without being specific about the purpose of debt financing. The RDEBT is used as a proxy for the unobserved dollar debt, because it is positively correlated with the amount of dollar debt. We use the two-period lag of RDEBT to avoid an endogeneity problem, since its one-period lag influences our measure of real interest rates. In Table 2, the coefficient of the interaction between unexpected RER depreciation and two-period lagged RDEBT is identical to that of the interaction between unexpected RER depreciation and lagged RIIM in Table 1. Coefficients of other variables and their statistical significance are close to those in Table 1.

However, the implied balance sheet effect from Table 2 is not necessarily identical to that from Table 1 because the distribution of lagged RIIM and that of two-period lagged RDEBT are different. Based on the estimate in Table 2, the implied balance sheet effect of a $60 \%$ depreciation during the won crisis could increase the real interest rate for firms of which twoperiod lagged RDEBT is one standard deviation higher than other firms by $10.26 \%$. This magnitude is smaller than the implied balance sheet effect via the import finance channel by 1.44\%. This $1.44 \%$ difference lends support to the notion in the trade finance literature, such as Amiti and Weinstein (2011) and Feenstra et al. (2014) that loans for trade finance are riskier than loans for working capital. ${ }^{4}$

\footnotetext{
${ }^{4}$ Even if we consider the distribution of lagged RIIM in 1997 and that of two-period lagged RDEBT in 1997, the implied balance sheet effect on the firm-level real interest rate via the import finance channel will still be
} 
Table 2: Balance sheet effect of currency depreciation - Financing any expenditure

\begin{tabular}{|c|c|c|c|c|c|c|}
\hline $\begin{array}{l}\text { Dependent variable: } \\
\text { Firm-level real interest rate }\end{array}$ & $(1)$ & $(2)$ & $(3)$ & $(4)$ & $(5)$ & $(6)$ \\
\hline US real interest rate & $\begin{array}{l}1.051^{* * *} \\
(0.050)\end{array}$ & $\begin{array}{l}0.984^{* * *} \\
(0.048)\end{array}$ & $\begin{array}{l}1.085^{* * *} \\
(0.048)\end{array}$ & $\begin{array}{l}0.998^{* * *} \\
(0.046)\end{array}$ & $\begin{array}{l}1.088^{* * *} \\
(0.048)\end{array}$ & $\begin{array}{l}1.005^{* * *} \\
(0.045)\end{array}$ \\
\hline Expected $\Delta \ln (\mathrm{RER})$ & $\begin{array}{l}0.333^{* * *} \\
(0.029)\end{array}$ & $\begin{array}{l}0.337^{* * *} \\
(0.026)\end{array}$ & $\begin{array}{l}0.362^{* * *} \\
(0.028)\end{array}$ & $\begin{array}{l}0.364^{* * *} \\
(0.025)\end{array}$ & $\begin{array}{l}0.357^{* * *} \\
(0.029)\end{array}$ & $\begin{array}{l}0.367^{* * *} \\
(0.025)\end{array}$ \\
\hline Country credit risk & $\begin{array}{l}0.236^{* * *} \\
(0.017)\end{array}$ & $\begin{array}{l}0.219^{* * *} \\
(0.016)\end{array}$ & $\begin{array}{l}0.240^{* * *} \\
(0.016)\end{array}$ & $\begin{array}{l}0.226^{* * *} \\
(0.014)\end{array}$ & $\begin{array}{l}0.239 * * * \\
(0.016)\end{array}$ & $\begin{array}{l}0.228^{* * *} \\
(0.014)\end{array}$ \\
\hline $\begin{array}{l}\text { Unexpected } \Delta \ln (\mathrm{RER}) \\
\mathrm{x} \ln (\operatorname{RDEBT}(-2))\end{array}$ & $\begin{array}{l}0.001^{* * *} \\
(0.000)\end{array}$ & $\begin{array}{l}0.001^{* * *} \\
(0.000)\end{array}$ & $\begin{array}{l}0.001^{* * *} \\
(0.000)\end{array}$ & $\begin{array}{l}0.001^{* * *} \\
(0.000)\end{array}$ & $\begin{array}{l}0.001^{* * *} \\
(0.000)\end{array}$ & $\begin{array}{l}0.001^{* * *} \\
(0.000)\end{array}$ \\
\hline Debt to sales $(-2)$ & $\begin{array}{l}0.007^{* * *} \\
(0.001)\end{array}$ & $\begin{array}{l}0.009^{* * *} \\
(0.002)\end{array}$ & & & & \\
\hline Cash flow to sales $(-1)$ & & & $\begin{array}{l}-0.029^{* * *} \\
(0.006)\end{array}$ & $\begin{array}{l}-0.006 \\
(0.007)\end{array}$ & & \\
\hline Trade credit to sales $(-1)$ & & & & & $\begin{array}{l}-0.004 \\
(0.005)\end{array}$ & $\begin{array}{l}0.005 \\
(0.011)\end{array}$ \\
\hline Constant & $\begin{array}{l}4.388^{* * *} \\
(0.214)\end{array}$ & $\begin{array}{l}2.198^{* * *} \\
(0.731)\end{array}$ & $\begin{array}{l}4.780^{* * *} \\
(0.185)\end{array}$ & $\begin{array}{l}2.391^{* * *} \\
(0.727)\end{array}$ & $\begin{array}{l}4.565^{* * *} \\
(0.198)\end{array}$ & $\begin{array}{l}2.282^{* * *} \\
(0.733)\end{array}$ \\
\hline Sample size & 4,277 & 4,277 & 4,191 & 4,191 & 4,195 & 4,195 \\
\hline$R^{2}$ & 0.268 & 0.486 & 0.283 & 0.497 & 0.279 & 0.497 \\
\hline Firm FE & No & Yes & No & Yes & No & Yes \\
\hline
\end{tabular}

Note: $\quad$ Firm-level real interest $\operatorname{rate}(\mathrm{t})=$ (interest expenditure $(\mathrm{t}) /(0.5(\operatorname{debt}(\mathrm{t}-1)+\operatorname{debt}(\mathrm{t}))$ inflation(t))100. The unit of real interest rate, RER depreciation, debt to sales, cash flow to sales and trade credit to sales is \%. FE denotes fixed effects. Robust standard errors are in parentheses. $* * *, * *$ and $*$ denote $1 \%, 5 \%$ and $10 \%$ significance level, respectively.

Next, we consider an alternative measure of the real interest rate as the ratio of interest expenditure to debt in the current year. If the maturity periods of some debts are shorter than one year, this measure tends to overestimate the real interest rate, as paid-off debts are not recorded in the statistics. The estimation results are in Table 3. In this case, the balance sheet effect of unexpected RER depreciation is twice that in Table 1, implying that the estimated

larger than that via the working capital channel. In 1997, the standard deviation of lagged RIIM was larger than the standard deviation of two-period lagged real debts by 37\%. Based on these statistics, in 1997 the import finance channel could increase the firm-level real interest rate by $2.22 \%$ more than the working capital channel could do. 
balance sheet effect in Table 1 is a conservative estimate. The size of macro variable coefficients are similar to those found in Tables 1 and 2. The lagged cash flow to sales ratio continues to have a negative and significant impact when firm fixed effects are excluded. However, the lagged trade credit to sales ratio has a positive and significant impact when firm fixed effects are included. This suggests that an increase in trade credit may increase credit risk. The two-period lagged debt to sales ratio does not have a significant impact on the real interest rate.

Table 3: Balance sheet effect of currency depreciation - Financing imports with alternative interest rate

\begin{tabular}{|c|c|c|c|c|c|c|}
\hline $\begin{array}{l}\text { Dependent variable: } \\
\text { Firm-level real interest rate }\end{array}$ & $(1)$ & $(2)$ & $(3)$ & $(4)$ & $(5)$ & $(6)$ \\
\hline US real interest rate & $\begin{array}{l}1.165^{* * *} \\
(0.091)\end{array}$ & $\begin{array}{l}1.090^{* * *} \\
(0.095)\end{array}$ & $\begin{array}{l}1.171^{* * *} \\
(0.087)\end{array}$ & $\begin{array}{l}1.065^{* * *} \\
(0.089)\end{array}$ & $\begin{array}{l}1.173^{* * *} \\
(0.088)\end{array}$ & $\begin{array}{l}1.072^{* * *} \\
(0.090)\end{array}$ \\
\hline Expected $\Delta \ln (\mathrm{RER})$ & $\begin{array}{l}0.225^{* * *} \\
(0.038)\end{array}$ & $\begin{array}{l}0.232^{* * *} \\
(0.037)\end{array}$ & $\begin{array}{l}0.234^{* * *} \\
(0.038)\end{array}$ & $\begin{array}{l}0.236^{* * *} \\
(0.035)\end{array}$ & $\begin{array}{l}0.228^{* * *} \\
(0.038)\end{array}$ & $\begin{array}{l}0.235^{* * *} \\
(0.035)\end{array}$ \\
\hline Country credit risk & $\begin{array}{l}0.209^{* * *} \\
(0.031)\end{array}$ & $\begin{array}{l}0.203^{* * *} \\
(0.030)\end{array}$ & $\begin{array}{l}0.218^{* * *} \\
(0.027)\end{array}$ & $\begin{array}{l}0.213^{* * *} \\
(0.027)\end{array}$ & $\begin{array}{l}0.219^{* * *} \\
(0.027)\end{array}$ & $\begin{array}{l}0.218^{* * *} \\
(0.027)\end{array}$ \\
\hline $\begin{array}{l}\text { Unexpected } \Delta \ln (\text { RER }) \\
\mathrm{x} \ln (\operatorname{RIIM}(-1))\end{array}$ & $\begin{array}{l}0.002^{* * *} \\
(0.000)\end{array}$ & $\begin{array}{l}0.002^{* * *} \\
(0.000)\end{array}$ & $\begin{array}{l}0.002^{* * *} \\
(0.000)\end{array}$ & $\begin{array}{l}0.002^{* * *} \\
(0.000)\end{array}$ & $\begin{array}{l}0.002^{* * *} \\
(0.000)\end{array}$ & $\begin{array}{l}0.002^{* * *} \\
(0.000)\end{array}$ \\
\hline Debt to sales $(-2)$ & $\begin{array}{l}-0.001 \\
(0.002)\end{array}$ & $\begin{array}{l}-0.001 \\
(0.002)\end{array}$ & & & & \\
\hline Cash flow to sales $(-1)$ & & & $\begin{array}{l}-0.024^{* * *} \\
(0.008)\end{array}$ & $\begin{array}{l}-0.008 \\
(0.008)\end{array}$ & & \\
\hline Trade credit to sales $(-1)$ & & & & & $\begin{array}{l}0.007 \\
(0.006)\end{array}$ & $\begin{array}{l}0.019^{*} \\
(0.011)\end{array}$ \\
\hline Constant & $\begin{array}{l}4.897^{* * *} \\
(0.438)\end{array}$ & $\begin{array}{l}2.690^{* * *} \\
(1.035)\end{array}$ & $\begin{array}{l}5.147^{* * *} \\
(0.372)\end{array}$ & $\begin{array}{l}3.172^{* * *} \\
(1.023)\end{array}$ & $\begin{array}{l}5.106^{* * *} \\
(0.373)\end{array}$ & $\begin{array}{l}2.919^{* * *} \\
(1.023)\end{array}$ \\
\hline Sample size & 4,166 & 4,166 & 4,537 & 4,537 & 4,542 & 4,542 \\
\hline$R^{2}$ & 0.117 & 0.278 & 0.120 & 0.294 & 0.118 & 0.294 \\
\hline Firm FE & No & Yes & No & Yes & No & Yes \\
\hline
\end{tabular}

Note: Firm-level real interest rate(t) = (interest expenditure(t)/debt(t)-inflation(t))100. The unit of real interest rate, RER depreciation, debt to sales, cash flow to sales and trade credit to sales is $\%$. FE denotes fixed effects. Robust standard errors are in parentheses. ***,** and $*$ denote $1 \%, 5 \%$ and $10 \%$ significance level, respectively. 
To summarize, we find strong evidence for the balance sheet effect of unexpected RER depreciation on the firm-level real interest rate. In particular, firms in a sector which imports a larger value of intermediate inputs and firms carrying a larger amount of debt are found to pay higher real interest rates following an unexpected RER depreciation. The results imply that imported intermediate inputs are perceived as a type of risk to be monitored by lenders in a similar way to that of an increase in debt. This finding is novel and suggests that financing imports of intermediate inputs is a new channel through which unexpected RER depreciation influences exporting firms.

The role of imported intermediate inputs has been neglected by both theoretical and empirical studies on the balance sheet effect of unexpected RER depreciation. The existing studies, such as Aguiar (2005) and Kim et al. (2012), typically examine the balance sheet effect on investment, output and exports. Although Bleakley and Cowan (2008) test the balance sheet effect on financing costs, their measure of financing costs is the total of interest expenditures, not necessarily the interest rate. Moreover, their measure of expected exchange rate depreciation is the difference between dollar and local currency interest rates, implying that they are abstract from the country's credit risk as a determinant of financing costs.

In the next section, we incorporate imported intermediate inputs into a trade model in order to assess the impact of unexpected RER depreciation on firm-level exports.

\section{$3 \quad$ Exports and Real Exchange Rates}

In this section, we derive the equilibrium of firm-level exports by incorporating the costs of imported intermediate inputs and the costs of borrowing into the product differentiation model 
of trade. ${ }^{5}$ We demonstrate that, in addition to unexpected RER depreciation, multilateral RERs based on trade in both intermediate inputs and final products are important determinants of exports. Then, we discuss the construction of multilateral RERs and estimate their impact on firm-level exports.

\subsection{Exports and Real Exchange Rates: Theory}

Products are assumed to be differentiated by firms and firms are heterogeneous in the cost of production. This assumption is similar to those in Melitz (2003). However, we do not study the selection into exporting and assume that all firms are exporters. Hence, we abstract from fixed entry costs to export.

Suppose the final consumption is a composite of goods from various sectors with the elasticity of substitution $\theta>0$, and consumption in each sector is a similar composite of differentiated products with the same elasticity. In this type of product differentiation model, demand for product $f$ in sector $s$ exported from country $i$ to country $j$, denoted by $X_{f s i j}$, is determined by its buyer's price $p_{f s i j}$ relative to country $j$ 's price level $P_{j}$, and country $j$ 's real national income $Y_{j}$. Specifically, the logarithm of demand for bilateral exports of firm $f$ in sector $s$ takes the following form:

$$
\ln X_{f s i j}=-\theta \ln \left(p_{f s i j}\right)+\theta \ln \left(P_{j}\right)+\ln \left(Y_{j}\right)
$$

On the supply side, we assume that the exporting firm $f$ produces product $f$ using capital, labor and imported intermediate inputs from foreign countries. Suppose product prices are set in the seller's currency. Then, the buyer's currency price of export is a product of markup and

\footnotetext{
${ }^{5}$ See Anderson and van Wincoop (2004) for the literature survey.
} 
marginal cost adjusted by the exchange rate. Suppose the production technology is a CobbDouglas type. Then, the marginal cost is a geometric mean of input costs. For simplicity, assume no trade frictions. ${ }^{6}$ Therefore, we can decompose $\ln \left(p_{f s i j}\right)$ into the following:

$$
\ln \left(p_{f s i j}\right)=\mu_{s i}-\ln \left(E_{i j}\right)+\alpha_{s i} \ln \left(R_{f i}\right)+\delta_{s i} \sum_{k} \omega_{k s} \ln \left(p_{s i k}^{m}\right)+\left(1-\alpha_{s i}-\delta_{s i}\right) \ln \left(W_{f i}\right)-\ln \left(A_{s i}\right)
$$

where $\mu_{s i}=\ln (\theta)-\ln (\theta-1)-\alpha_{s i} \ln \left(\alpha_{s i}\right)-\delta_{s i} \ln \left(\delta_{s i}\right)-\left(1-\alpha_{s i}-\delta_{s i}\right) \ln \left(1-\alpha_{s i}-\delta_{s i}\right)$. The parameters $\alpha_{s i}\left(0<\alpha_{s i}<1\right)$ and $\delta_{s i}\left(0<\delta_{s i}<1\right)$ are sector-country specific cost shares of capital and imported intermediate input, respectively. The exchange rate $E_{i j}$ is pair-specific and defined as units of currency $i$ per unit of currency $j . R_{f i}$ denotes the firm-country specific rental on capital. The price $p_{s i k}^{m}$ is the currency $i$ 's price of imported intermediate input in sector $s$ from source country $k$ where the share of source country $k$ in sector $s$ is $\omega_{k s}$. $W_{f i}$ denotes firm-country specific wage, and $A_{s i}$ denotes sector-country specific total factor productivity.

Note that equation (4) holds regardless of the currency of price setting for two reasons. First, the frequency in our data set is annual, therefore we assume that goods prices are flexible and the currency of price setting does not matter. Second, exporters evaluate profits in their currency.

Let $\omega_{j s}$ be the share of country $j$ in total exports from firm $f$ in sector $s$. Substituting (4) into (3), multiplying it with $\omega_{j s}$ and then aggregating over destination country $j$ yields $\sum_{j} \omega_{j s} \ln X_{f s i j}$. We show in the appendix that this summation is an approximation of $\ln \left(\sum_{j} X_{f s i j}\right)$ or the logarithm of the sum of firm-level exports over all destination. To be precise, define the sum of firm-level exports over all destinations as $X_{f s i}=\sum_{j}^{N_{x}} X_{f s i j}$, where

\footnotetext{
${ }^{6}$ We relax this assumption in the estimation.
} 
$N_{x}$ denotes the number of exporting destinations. We define the RER between country $i$ and $j$ in a logarithm as $\ln \left(R E R_{i j}\right)=\ln \left(E_{i j}\right)+\ln \left(P_{j}\right)-\ln \left(P_{i}\right)$. Let us denote the number of sources of intermediate inputs by $N_{m}$. Define the import-weighted multilateral RER in a logarithm as

$$
\ln \left(M R E R_{s i}\right)=\sum_{k}^{N_{m}} \omega_{k s} \ln \left(R E R_{i k}\right),
$$

where $\omega_{k s}$ is the share of source country $k$ in total imported intermediate inputs of firms in sector $s$. Likewise, define the export-share weighted multilateral RER in a logarithm as

$$
\ln \left(X R E R_{s i}\right)=\sum_{j}^{N_{x}} \omega_{j s} \ln \left(R E R_{i j}\right) .
$$

Define the export-share weighted real GDP of the buyer's countries in a logarithm as

$$
\ln \left(R G D P_{s i}\right)=\sum_{j}^{N_{x}} \omega_{j s} \ln \left(Y_{j}\right) .
$$

We show in the appendix that, in equilibrium, the quantity of total exports by firm $f$ in sector $s$ in country $i$ is as follows:

$$
\begin{aligned}
\ln \left(X_{f s i}\right)= & -\theta \mu_{s i}-\theta \alpha_{s i} r_{f i}-\theta \delta_{s i} \ln \left(\operatorname{MRER}_{s i}\right)+\theta \ln \left(\text { XRER } R_{s i}\right) \\
& -\theta \delta_{s i} \sum_{k}^{N_{m}} \omega_{s k}\left(\ln \left(p_{s i k}^{\star m}\right)-\ln \left(P_{k}\right)\right)-\theta\left(1-\alpha_{s i}-\delta_{s i}\right) \ln \left(w_{f i}\right) \\
& +\theta \ln \left(A_{s i}\right)+\ln \left(R G D P_{s i}\right)-\left(\frac{X_{f s i}}{\Pi_{j}^{N_{x}} X_{f s i j}}-1\right)
\end{aligned}
$$

where $p_{s i k}^{\star m}$ denotes the price of intermediate inputs in source country $k$ 's currency, $r_{f i}$ denotes the real costs of debt financing or the firm-level real interest rate or $\ln \left(R_{f i}\right)-\ln \left(P_{i}\right)$, and $w_{f i}$ denotes the real wage or $W_{f i} / P_{i}$. The last term in equation (5) is a discrepancy from the Taylor approximation, and it depends on the dispersion of exports across destinations. In the extreme 
case, when exports to all destinations occupy the same share in total exports, this discrepancy is zero.

According to (5), movements in RERs have two competing effects on exports. First, the MRER depreciation has a negative effect on exports, because that increases the costs of imported intermediate inputs in the exporter's currency. Second, the XRER depreciation has a positive effect on exports, because that improves the price competitiveness of exporters.

Differentiating the XRER and the MRER is crucial in our framework, because firms in our study are vertically integrated firms and we place no restrictions on the set of source countries and the set of exporting destinations. Vertically integrated firms may import inputs from countries that they do not export to. As a result, the RER that firms face as buyers of inputs may be different from the RER that firms face as sellers of outputs. The effect of currency depreciation on exports then depends on the net effect of relative prices and the trade pattern. This point is also emphasized by Bems and Johnson (2012), who attempt to construct the value-added based multilateral RERs.

Finally, given the real interest rate regression in equation (2), equation (5) gives the following estimating equation:

$$
\ln X_{f s t}=\xi_{0}+\boldsymbol{\xi}_{r} \mathbf{V}_{\mathrm{fst}}+\xi_{1} \ln M R E R_{s t}+\xi_{2} \ln X R E R_{s t}+\boldsymbol{\xi}_{z} \mathbf{Z}_{\mathrm{fst}}+F E_{f}+F E_{s}+\epsilon_{f s t},(6)
$$

where elements of vector $\mathbf{V}_{\text {fst }}$ are determinants of the firm-level real interest rate in equation (2), and elements of vector $\mathbf{Z}_{\text {fst }}$ are other controls in logarithms. The $\mathbf{V}_{\text {fst }}$ takes into account the balance sheet effect of unexpected RER depreciation through import financing or debt financing for any purposes. Other controls in vector $\mathbf{Z}_{\mathrm{fst}}$ are the sector-specific export-share 
weighted sum of the real GDP of destination countries, firm-specific average real wage, sectorspecific total factor productivity, and a proxy for trade costs. The firm fixed effect and the sector fixed effect are denoted by $F E_{f}$ and $F E_{s}$, respectively. These fixed effects are included to mitigate omitted variable bias, because some time-invariant firm- and sector-specific factors can affect exports.

The error term $\epsilon_{f s i}$ includes the average deviation of the prices of imported intermediate inputs from the source country's price level and the discrepancy from the Taylor approximation. However, the discrepancy depends on the share of each destination in total exports, not exactly total exports to all destinations. Hence, omitting this term does not clearly indicate an endogeneity problem. As for omitting the average deviation of the prices of imported intermediate inputs from the source country's price level, this is equivalent to assuming that the retail markup in source countries is identical across sectors and constant over time. This assumption is true if the following two conditions hold. One, preferences in all trading partners also features a constant elasticity of substitution. This is exactly what we assume in the previous section. Two, distribution costs are identical for all sectors. This condition is not satisfied in the data, as documented by Crucini, Telmer and Zachariadis (2005). However, the sector fixed effect has controlled for cross-sectional differences in distribution costs.

Although equation (5) suggests that the coefficients of the MRER are sector-specific, our strategy is to assume that they are common across sectors. This restriction enables us to exploit the cross-sectional variation of XRERs and MRERs, and to increase the degree of freedom. 


\subsection{Exports and Real Exchange Rates: Data}

We calculate the real export by deflating the value of exports with Korea's CPI from the IFS. The CPI and exchange rates used in the construction of multilateral RERs are also from the same database. We use shares of imports and exports for the top-10 trading partners, and the set of top-10 trading partners varies over time. Thus, the set of top-10 trading partners generates cross-sectional variation, which is useful for identification. On average, these top-10 trading partners account for $74-86 \%$ of the value of Korea's trade.

We use bilateral flows of exports and imports from the UN Comtrade Database to construct the export share $\omega_{j s}$ and import share $\omega_{k s}$. The trade flows data are classified by both SITC and HS codes. We reclassify them to 13 NAICS codes using 10-digit HS codes as a bridge to connect SITC Rev.3 and 4-digit NAICS, because we classify firms into 13 sectors based on the NAICS. ${ }^{7}$

Since our data set has only one country, henceforth we drop the subscript $i$ and introduce the subscript $t$ to emphasize the time series variation. In practice consumption baskets are different across countries, therefore levels of RERs are not comparable. For this reason, we use percentage changes in the RER to calculate percentage changes in the XRER, and then use them to obtain levels of the XRER conditioning on the given initial level:

$$
\begin{aligned}
\Delta \ln \left(X R E R_{s t}\right) & =\sum_{j}^{N_{x}} \omega_{s j t} \Delta \ln \left(R E R_{j t}\right) \\
\ln \left(X R E R_{s t}\right) & =\Delta \ln \left(X R E R_{s t}\right)+\ln \left(X R E R_{s, t-1}\right)
\end{aligned}
$$

\footnotetext{
${ }^{7}$ We reclassify trade flows data to NAICS codes in two steps. First, we employ concordance between the 10-digit HS and SITC Rev.3. Next, we employ concordance between the 10-digit HS and 4-digit NAICS codes. Concordance between HS and SITC and concordance between HS and NAICS are from Pierce and Schott (2009).
} 
where $X R E R_{s 0}=100$. Note that we employ the time-variant export share weight to take into account changes in the export pattern, as in Goldberg (2004).

Likewise, we compute the import-share weighted multilateral RER using a similar technique and imposing an additional assumption about the structure of imports. To be precise, we impose the proportionality assumption that source country $k$ 's share in country $i$ 's imports of intermediate inputs is identical to its share in total imports, as in Hummels et al. (2001) and Trefler and Zhu (2010). According to the proportionality assumption, if $30 \%$ of the Korean absorption of machinery is sourced from Japan, then $30 \%$ of any Korean sector's use of machinery originates from Japan. Let $a_{s s^{\prime} t}$ be the share of input $s^{\prime}$ used in the production of output in sector $s$ in year $t$, and the number of $s^{\prime}$ be $N_{s}^{\prime}$. If a fraction $\omega_{k s t}$ of the Korean absorption of sector $s^{\prime}$ is sourced from country $k$, then the same fraction $\omega_{k s t}$ of any Korean sector's use of sector $s^{\prime}$ originates from country $k$.

$$
a_{s s^{\prime} t} \sum_{k=1}^{N_{m}} w_{k s t}=\sum_{k=1}^{N_{m}} w_{k s t} a_{s s^{\prime} t}
$$

We computed the share $a_{s s^{\prime} t}$ using Korea's input-output table from the Bank of Korea. However, the input-output table is not available every year. For missing years, we obtain the input coefficient from the average of the previous year and the subsequent year. ${ }^{8}$ We match the import-share data in 24 NAICS industries with 13 industries in the input-output table, as classified by the Bank of Korea.

With the proportionality assumption, a nominal depreciation of the Korean won against currency $k$ raises the price of imported inputs in the won, depending on the import share $\omega_{k s t}$

\footnotetext{
${ }^{8}$ Missing years are 1991, 1992, 1994, 1996, 1997, 2001, 2002, and 2004.
} 
and the input-output coefficient $a_{s s^{\prime} t}$ :

$$
\begin{aligned}
\Delta \ln \left(M R E R_{s t}\right) & =\sum_{k=1}^{N_{m}} \sum_{s^{\prime}=1}^{N_{s}^{\prime}} \omega_{k s t} a_{s s^{\prime} t} \Delta \ln \left(R E R_{k t}\right), \\
\ln \left(M R E R_{s t}\right) & =\Delta \ln \left(M R E R_{s t}\right)+\ln \left(M R E R_{s, t-1}\right),
\end{aligned}
$$

where $M R E R_{s 0}=100$.

Figure 7 shows the average of the logarithms of the two multilateral RERs within each sector over time. The cross-sectional variation is not great, but still there is a variation across industries. Sector 5, petroleum and coal products, has the highest level of $\ln (X R E R)$, meaning that this is on average the most competitive sector. Sector 3, textile and apparel, shows the highest level of $\ln (M R E R)$, meaning that its imported intermediate inputs are the most costly.

The time-series variation of the logarithms of multilateral RERs is displayed in Figure 8. Unlike the time-series variation in the real interest rate, the XRER and the MRER rose sharply in 1997 when the Asian Crisis started. These two multilateral RERs move together over time, because in many sectors the set of destination countries for exports is quite similar to the set of source countries for imports of intermediate inputs.

Total factor productivity is obtained as the Solow's residual. ${ }^{9}$ For the proxy for trade costs, we use the sector-specific export-share weighted sum of bilateral distance at a given point in time. The bilateral distance data are from the French Research Center in International Economics or CEPII ${ }^{10}$.

\footnotetext{
${ }^{9}$ See the Appendix.

${ }^{10}$ The CEPII provides distance data at the following website: http://www.cepii.fr/anglaisgraph/bdd/distances.htm
} 
Figure 7: Average of log of export-weighted multilateral RER and import-weighted multilateral RER over time within each sector

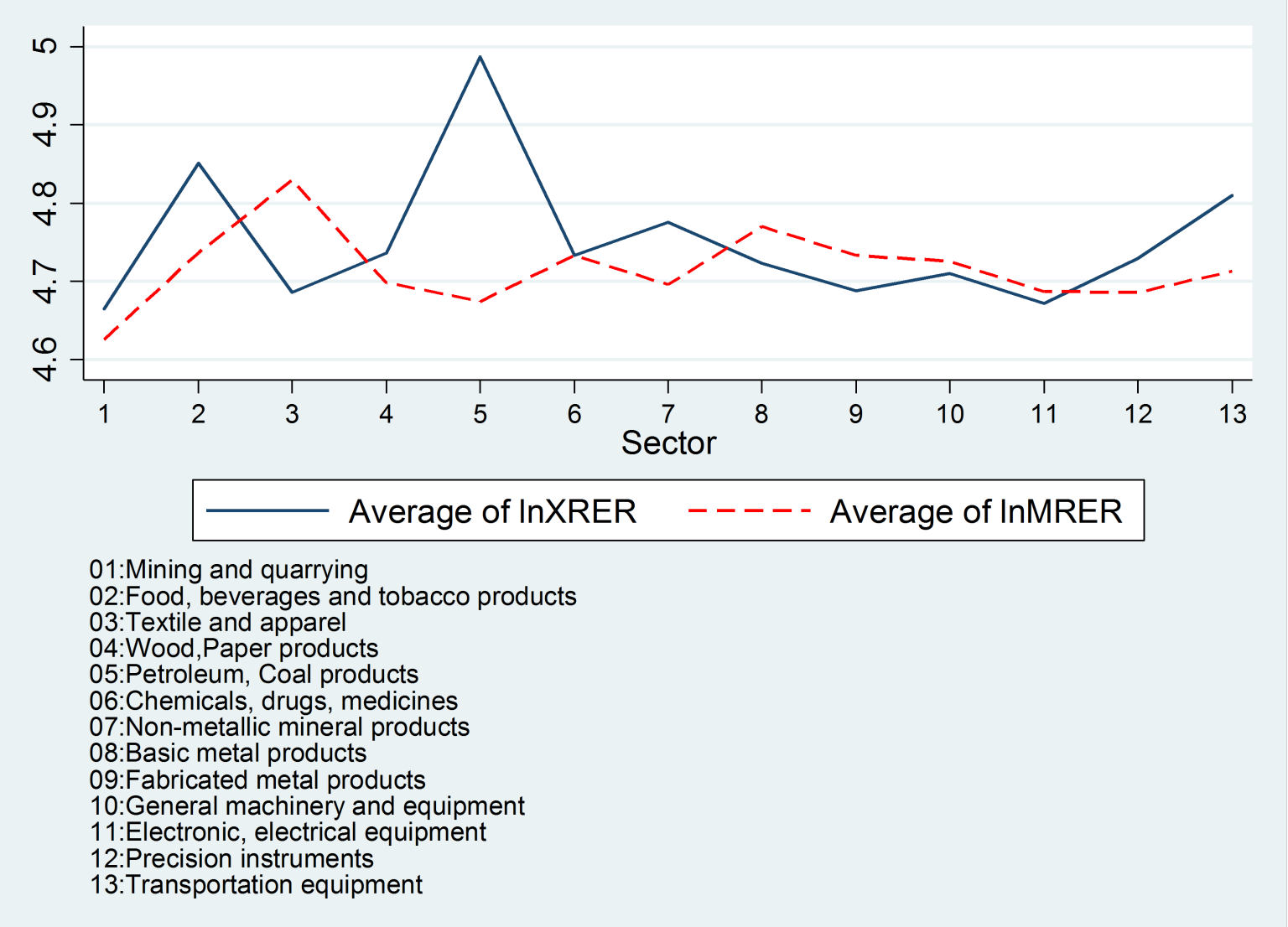

Note: Top-10 exporting destinations and top-10 importing sources are included in the calculation of export-weighted multilateral RER and import-weighted multilateral RER, respectively.

\subsection{Exports and Real Exchange Rates: Evidence}

Table 4 shows the baseline results of the exports regression in (6). The balance sheet effect is captured by the interaction of unexpected RER depreciation with lagged imports of intermediate inputs in columns 1-3, and with lagged debt in columns 4-6. In all specifications, the estimated coefficients of the balance sheet and other variables except for the US real interest rate, country-level risk have the expected sign and statistically significant. The sign of the 
Figure 8: Average of log of export-share weighted multilateral RER and import-share weighted multilateral RER over all sectors

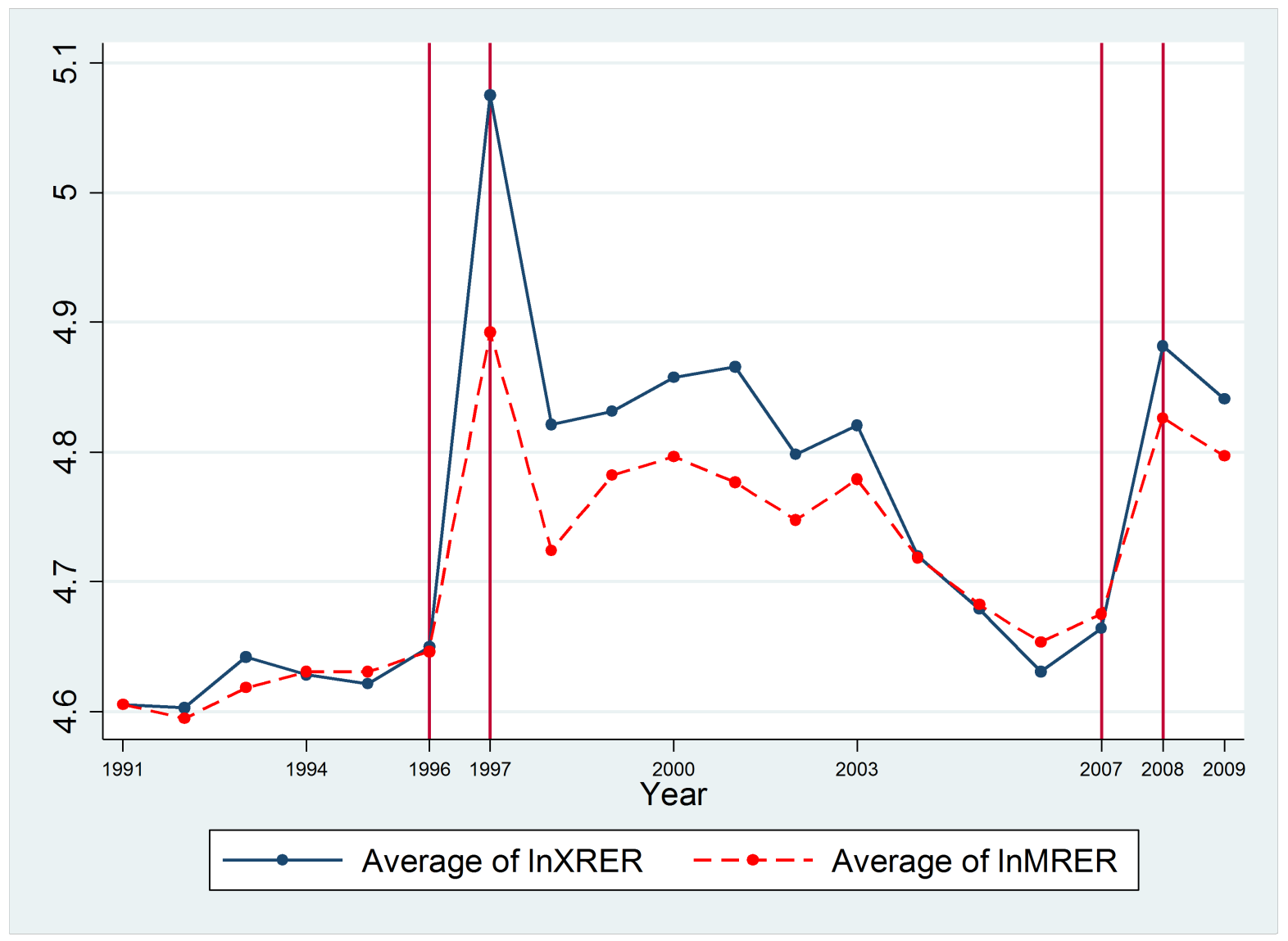

Note: Top-10 exporting destinations and top-10 importing sources are included in the calculation of export-weighted multilateral RER and import-weighted multilateral RER, respectively.

expected RER deprecation is opposite to our expectation, but it is not statistically different from zero.

Quantitatively, a 1\% unexpected RER depreciation and one standard deviation (195\%) increase in imports of intermediate inputs reduces exports by 3.90\%. A 1\% unexpected RER depreciation and one standard deviation (171\%) increase in debt reduces exports by $5.13 \%$. These are quite large balance sheet effects. As for the impact of unexpected RER depreciation in the goods market, a $1 \%$ depreciation in the MRER decreases exports by $0.96-1.13 \%$, and a 
Table 4: Determinants of firm-level real exports - Baseline results

\begin{tabular}{|c|c|c|c|c|c|c|}
\hline $\begin{array}{l}\text { Dependent variable: } \\
\ln \text { (real exports) }\end{array}$ & $(1)$ & $(2)$ & $(3)$ & $(4)$ & $(5)$ & $(6)$ \\
\hline US real interest rate & $\begin{array}{l}-0.024 \\
(0.015)\end{array}$ & $\begin{array}{l}-0.012 \\
(0.015)\end{array}$ & $\begin{array}{l}-0.012 \\
(0.015)\end{array}$ & $\begin{array}{l}-0.021 \\
(0.015)\end{array}$ & $\begin{array}{l}-0.024 \\
(0.015)\end{array}$ & $\begin{array}{l}-0.025^{*} \\
(0.015)\end{array}$ \\
\hline Expected $\Delta \ln (\mathrm{RER})$ & $\begin{array}{l}0.010 \\
(0.007)\end{array}$ & $\begin{array}{l}0.008 \\
(0.007)\end{array}$ & $\begin{array}{l}0.006 \\
(0.007)\end{array}$ & $\begin{array}{l}0.010 \\
(0.007)\end{array}$ & $\begin{array}{l}0.006 \\
(0.007)\end{array}$ & $\begin{array}{l}0.004 \\
(0.007)\end{array}$ \\
\hline Country credit risk & $\begin{array}{l}-0.002 \\
(0.006)\end{array}$ & $\begin{array}{l}-0.003 \\
(0.006)\end{array}$ & $\begin{array}{l}-0.005 \\
(0.006)\end{array}$ & $\begin{array}{l}-0.003 \\
(0.006)\end{array}$ & $\begin{array}{l}-0.003 \\
(0.006)\end{array}$ & $\begin{array}{l}-0.005 \\
(0.006)\end{array}$ \\
\hline $\begin{array}{l}\text { Unexpected } \Delta \ln (\text { RER }) \\
x \ln (\operatorname{RIIM}(-1))\end{array}$ & $\begin{array}{l}-0.0002^{* * *} \\
(0.000)\end{array}$ & $\begin{array}{l}-0.0002^{* * *} \\
(0.000)\end{array}$ & $\begin{array}{l}-0.0003^{* * *} \\
(0.000)\end{array}$ & & & \\
\hline $\begin{array}{l}\text { Unexpected } \Delta \ln (\mathrm{RER}) \\
\mathrm{x} \ln (\operatorname{RDEBT}(-2))\end{array}$ & & & & $\begin{array}{l}-0.0003^{* * *} \\
(0.000)\end{array}$ & $\begin{array}{l}-0.0003^{* * *} \\
(0.000)\end{array}$ & $\begin{array}{l}-0.0003^{* * *} \\
(0.000)\end{array}$ \\
\hline Debt to sales $(-2)$ & $\begin{array}{l}-0.002^{* * *} \\
(0.001)\end{array}$ & & & $\begin{array}{l}-0.002^{* * *} \\
(0.001)\end{array}$ & & \\
\hline Cash flow to sales $(-1)$ & & $\begin{array}{l}0.005^{* * *} \\
(0.002)\end{array}$ & & & $\begin{array}{l}0.006^{* * *} \\
(0.002)\end{array}$ & \\
\hline Trade credit to sales $(-1)$ & & & $\begin{array}{l}0.005^{* * *} \\
(0.002)\end{array}$ & & & $\begin{array}{l}0.006^{* * *} \\
(0.002)\end{array}$ \\
\hline $\ln (\mathrm{XRER})$ & $\begin{array}{l}0.429^{* *} \\
(0.201)\end{array}$ & $\begin{array}{l}0.407^{* *} \\
(0.202)\end{array}$ & $\begin{array}{l}0.496^{* *} \\
(0.200)\end{array}$ & $\begin{array}{l}0.454^{* *} \\
(0.200)\end{array}$ & $\begin{array}{l}0.411^{* *} \\
(0.202)\end{array}$ & $\begin{array}{l}0.518^{* * *} \\
(0.199)\end{array}$ \\
\hline $\ln (\mathrm{MRER})$ & $\begin{array}{l}-0.982^{* * * *} \\
(0.213)\end{array}$ & $\begin{array}{l}-1.088^{* * * *} \\
(0.225)\end{array}$ & $\begin{array}{l}-1.040^{* * * *} \\
(0.226)\end{array}$ & $\begin{array}{l}-0.958^{* * *} \\
(0.215)\end{array}$ & $\begin{array}{l}-1.131^{* * * *} \\
(0.208)\end{array}$ & $\begin{array}{l}-1.079^{* * *} \\
(0.208)\end{array}$ \\
\hline $\ln (\mathrm{RGDP})$ & $\begin{array}{l}1.331^{* * *} \\
(0.161)\end{array}$ & $\begin{array}{l}1.639^{* * *} \\
(0.162)\end{array}$ & $\begin{array}{l}1.556^{* * *} \\
(0.159)\end{array}$ & $\begin{array}{l}1.321^{* * *} \\
(0.161)\end{array}$ & $\begin{array}{l}1.427^{* * *} \\
(0.160)\end{array}$ & $\begin{array}{l}1.324^{* * *} \\
(0.156)\end{array}$ \\
\hline $\ln$ (real wage) & $\begin{array}{l}-0.452^{* * *} \\
(0.063)\end{array}$ & $\begin{array}{l}-0.441^{* * *} \\
(0.058)\end{array}$ & $\begin{array}{l}-0.441^{* * *} \\
(0.058)\end{array}$ & $\begin{array}{l}-0.453^{* * *} \\
(0.063)\end{array}$ & $\begin{array}{l}-0.422^{* * *} \\
(0.060)\end{array}$ & $\begin{array}{l}-0.422^{* * *} \\
(0.060)\end{array}$ \\
\hline $\ln (\mathrm{TFP})$ & $\begin{array}{l}0.868^{* * *} \\
(0.078)\end{array}$ & $\begin{array}{l}0.866^{* * *} \\
(0.079)\end{array}$ & $\begin{array}{l}0.879^{* * *} \\
(0.079)\end{array}$ & $\begin{array}{l}0.867^{* * *} \\
(0.078)\end{array}$ & $\begin{array}{l}0.877^{* * *} \\
(0.080)\end{array}$ & $\begin{array}{l}0.887^{* * *} \\
(0.080)\end{array}$ \\
\hline $\ln ($ distance $)$ & $\begin{array}{l}-0.186^{* *} \\
(0.084)\end{array}$ & $\begin{array}{l}-0.252^{* * * *} \\
(0.088)\end{array}$ & $\begin{array}{l}-0.248^{* * *} \\
(0.088)\end{array}$ & $\begin{array}{l}-0.185^{* *} \\
(0.084)\end{array}$ & $\begin{array}{l}-0.186^{* *} \\
(0.084)\end{array}$ & $\begin{array}{l}-0.191^{* *} \\
(0.084)\end{array}$ \\
\hline Constant & $\begin{array}{l}15.17^{* * *} \\
(1.191)\end{array}$ & $\begin{array}{l}14.53^{* * *} \\
(1.253)\end{array}$ & $\begin{array}{l}14.30^{* * *} \\
(1.247)\end{array}$ & $\begin{array}{l}14.98^{* * *} \\
(1.189)\end{array}$ & $\begin{array}{l}15.20^{* * *} \\
(1.166)\end{array}$ & $\begin{array}{l}15.03^{* * *} \\
(1.160)\end{array}$ \\
\hline Sample size & 4,261 & 4,640 & 4,645 & 4,261 & 4,175 & 4,179 \\
\hline$R^{2}$ & 0.897 & 0.882 & 0.882 & 0.897 & 0.897 & 0.897 \\
\hline Firm FE & Yes & Yes & Yes & Yes & Yes & Yes \\
\hline Sector FE & Yes & Yes & Yes & Yes & Yes & Yes \\
\hline
\end{tabular}

Note: The unit of real interest rate, RER depreciation, debt to sales, cash flow to sales and trade credit to sales is \%. FE denotes fixed effects. Robust standard errors are in parentheses. $* * *, * *$ and * denote $1 \%, 5 \%$ and $10 \%$ significance level, respectively. 
$1 \%$ depreciation in the XRER increases exports by $0.41-0.52 \% .^{11}$

Suppose that the RER depreciation arises from the nominal depreciation of the won, holding price levels in Korea and all trading partners constant. Then, the estimated coefficients of MRER and XRER imply that a $1 \%$ won depreciation against all trading partners' currencies results in an overall reduction in exports by $0.48-0.67 \%$. This contractionary effect of depreciation has not taken into account the balance sheet effect. Therefore, the overall contractionary effect of RER depreciation could be larger than $0.67 \%$, depending on the value of intermediate inputs or debt. As discussed above, the firm whose lagged RIIM is one standard deviation larger would experience an additional 3.9\% reduction in exports. In this case, the overall drop in exports in response to $1 \%$ won depreciation would be larger than $4 \%$.

For the firm's risk unrelated to unexpected RER depreciation, we find strong evidence for the negative impact of credit risk and positive impact of liquidity on exports. A $1 \%$ increase in the two-period lagged ratio of debt to sales decreases exports by $0.2 \%$. A $1 \%$ increase in the lagged ratio of cash flow to sales or the lagged trade credit to sales increase exports by $0.5-0.6 \%$.

It is important to test whether our specifications have captured the effects of large financial shocks during financial crises. We do so by including two different windows of financial crisis dummies to test how long the crisis effect lasted. The results are shown in Tables 5 and 6 . In Table 5, the financial crisis dummy is defined as 1 in 1997 or 2008 and zero otherwise. The estimated coefficients of the financial crisis dummy are not significant in all specifications.

\footnotetext{
${ }^{11}$ The size of estimated coefficients of XRER are actually larger than those of total factor productivity, although the estimating equation predicts that they must be identical. This is because in practice exporting goods incurs trade costs not related to distance, such as tariffs and insurance.
} 
Table 5: Determinants of firm-level real exports - Role of financial crisis

\begin{tabular}{|c|c|c|c|c|c|c|}
\hline $\begin{array}{l}\text { Dependent variable: } \\
\ln \text { (real exports) }\end{array}$ & (1) & $(2)$ & $(3)$ & $(4)$ & $(5)$ & $(6)$ \\
\hline Financial crisis & $\begin{array}{l}-0.004 \\
(0.098)\end{array}$ & $\begin{array}{l}0.108 \\
(0.100)\end{array}$ & $\begin{array}{l}0.114 \\
(0.100)\end{array}$ & $\begin{array}{l}0.022 \\
(0.095)\end{array}$ & $\begin{array}{l}0.069 \\
(0.095)\end{array}$ & $\begin{array}{l}0.074 \\
(0.095)\end{array}$ \\
\hline US real interest rate & $\begin{array}{l}-0.024 \\
(0.015)\end{array}$ & $\begin{array}{l}-0.005 \\
(0.015)\end{array}$ & $\begin{array}{l}-0.005 \\
(0.015)\end{array}$ & $\begin{array}{l}-0.020 \\
(0.015)\end{array}$ & $\begin{array}{l}-0.019 \\
(0.015)\end{array}$ & $\begin{array}{l}-0.020 \\
(0.015)\end{array}$ \\
\hline Expected $\Delta \ln (\mathrm{RER})$ & $\begin{array}{l}0.010 \\
(0.007)\end{array}$ & $\begin{array}{l}0.010 \\
(0.007)\end{array}$ & $\begin{array}{l}0.008 \\
(0.007)\end{array}$ & $\begin{array}{l}0.010 \\
(0.007)\end{array}$ & $\begin{array}{l}0.007 \\
(0.007)\end{array}$ & $\begin{array}{l}0.005 \\
(0.007)\end{array}$ \\
\hline Country credit risk & $\begin{array}{l}-0.002 \\
(0.006)\end{array}$ & $\begin{array}{l}-0.006 \\
(0.007)\end{array}$ & $\begin{array}{l}-0.007 \\
(0.007)\end{array}$ & $\begin{array}{l}-0.004 \\
(0.006)\end{array}$ & $\begin{array}{l}-0.005 \\
(0.007)\end{array}$ & $\begin{array}{l}-0.007 \\
(0.006)\end{array}$ \\
\hline $\begin{array}{l}\text { Unexpected } \Delta \ln (\text { RER }) \\
\mathrm{x} \ln (\operatorname{RIIM}(-1))\end{array}$ & $\begin{array}{l}-0.0002^{* * *} \\
(0.000)\end{array}$ & $\begin{array}{l}-0.0003^{* * *} \\
(0.000)\end{array}$ & $\begin{array}{l}-0.0003^{* * *} \\
(0.000)\end{array}$ & & & \\
\hline $\begin{array}{l}\text { Unexpected } \Delta \ln (\text { RER }) \\
x \ln (\operatorname{RDEBT}(-2))\end{array}$ & & & & $\begin{array}{l}-0.0003^{* * *} \\
(0.000)\end{array}$ & $\begin{array}{l}-0.0004^{* * *} \\
(0.000)\end{array}$ & $\begin{array}{l}-0.0004^{* * *} \\
(0.000)\end{array}$ \\
\hline Debt to sales(-2) & $\begin{array}{l}-0.002^{* * *} \\
(0.001)\end{array}$ & & & $\begin{array}{l}-0.002^{* * *} \\
(0.001)\end{array}$ & & \\
\hline Cash flow to sales $(-1)$ & & $\begin{array}{l}0.005^{* * *} \\
(0.002)\end{array}$ & & & $\begin{array}{l}0.006^{* * *} \\
(0.002)\end{array}$ & \\
\hline Trade credit to sales $(-1)$ & & & $\begin{array}{l}0.005^{* * *} \\
(0.002)\end{array}$ & & & $\begin{array}{l}0.006^{* * *} \\
(0.002)\end{array}$ \\
\hline $\ln (\mathrm{XRER})$ & $\begin{array}{l}0.428^{* *} \\
(0.206)\end{array}$ & $\begin{array}{l}0.444^{* *} \\
(0.207)\end{array}$ & $\begin{array}{l}0.536^{* * *} \\
(0.206)\end{array}$ & $\begin{array}{l}0.461^{* *} \\
(0.204)\end{array}$ & $\begin{array}{l}0.434^{* *} \\
(0.206)\end{array}$ & $\begin{array}{l}0.543^{* * *} \\
(0.203)\end{array}$ \\
\hline $\ln (\mathrm{MRER})$ & $\begin{array}{l}-0.981^{* * *} \\
(0.212)\end{array}$ & $\begin{array}{l}-1.106^{* * *} \\
(0.224)\end{array}$ & $\begin{array}{l}-1.059^{* * *} \\
(0.225)\end{array}$ & $\begin{array}{l}-0.962^{* * *} \\
(0.213)\end{array}$ & $\begin{array}{l}-1.144^{* * *} \\
(0.207)\end{array}$ & $\begin{array}{l}-1.093^{* * *} \\
(0.207)\end{array}$ \\
\hline $\ln (\mathrm{RGDP})$ & $\begin{array}{l}1.333^{* * *} \\
(0.171)\end{array}$ & $\begin{array}{l}1.585^{* * *} \\
(0.174)\end{array}$ & $\begin{array}{l}1.499^{* * *} \\
(0.171)\end{array}$ & $\begin{array}{l}1.311^{* * *} \\
(0.170)\end{array}$ & $\begin{array}{l}1.395^{* * *} \\
(0.169)\end{array}$ & $\begin{array}{l}1.288^{* * *} \\
(0.166)\end{array}$ \\
\hline $\ln$ (real wage) & $\begin{array}{l}-0.452^{* * *} \\
(0.063)\end{array}$ & $\begin{array}{l}-0.442^{* * *} \\
(0.059)\end{array}$ & $\begin{array}{l}-0.442^{* * *} \\
(0.058)\end{array}$ & $\begin{array}{l}-0.453^{* * *} \\
(0.063)\end{array}$ & $\begin{array}{l}-0.422^{* * *} \\
(0.060)\end{array}$ & $\begin{array}{l}-0.422^{* * *} \\
(0.060)\end{array}$ \\
\hline $\ln (\mathrm{TFP})$ & $\begin{array}{l}0.868^{* * *} \\
(0.078)\end{array}$ & $\begin{array}{l}0.867^{* * *} \\
(0.079)\end{array}$ & $\begin{array}{l}0.879 * * * \\
(0.079)\end{array}$ & $\begin{array}{l}0.867^{* * *} \\
(0.078)\end{array}$ & $\begin{array}{l}0.877^{* * *} \\
(0.080)\end{array}$ & $\begin{array}{l}0.887^{* * *} \\
(0.080)\end{array}$ \\
\hline $\ln ($ distance $)$ & $\begin{array}{l}-0.186^{* *} \\
(0.084)\end{array}$ & $\begin{array}{l}-0.249^{* * *} \\
(0.088)\end{array}$ & $\begin{array}{l}-0.245^{* * *} \\
(0.088)\end{array}$ & $\begin{array}{l}-0.184^{* *} \\
(0.084)\end{array}$ & $\begin{array}{l}-0.184^{* *} \\
(0.084)\end{array}$ & $\begin{array}{l}-0.189^{* *} \\
(0.084)\end{array}$ \\
\hline Constant & $\begin{array}{l}15.17^{* * * *} \\
(1.188)\end{array}$ & $\begin{array}{l}14.64^{* * *} \\
(1.249)\end{array}$ & $\begin{array}{l}14.41^{* * *} \\
(1.242)\end{array}$ & $\begin{array}{l}15.01^{* * *} \\
(1.185)\end{array}$ & $\begin{array}{l}15.27^{* * *} \\
(1.163)\end{array}$ & $\begin{array}{l}15.11^{* * *} \\
(1.157)\end{array}$ \\
\hline Sample size & 4,261 & 4,640 & 4,645 & 4,261 & 4,175 & 4,179 \\
\hline$R^{2}$ & 0.897 & 0.882 & 0.882 & 0.897 & 0.897 & 0.897 \\
\hline Firm FE & Yes & Yes & Yes & Yes & Yes & Yes \\
\hline Sector FE & Yes & Yes & Yes & Yes & Yes & Yes \\
\hline
\end{tabular}

Note: The financial crisis dummy is 1 for the years 1997 and 2008, and 0 for other years. The unit of real interest rate, RER depreciation, debt to sales, cash flow to sales and trade credit to sales is $\%$. $\mathrm{FE}$ denotes fixed effects. Robust standard errors are in parentheses. $* * *, * *$ and $*$ denote $1 \%, 5 \%$ and $10 \%$ significance level, respectively. 
Table 6: Determinants of firm-level real exports - Financial crisis with two-year window

\begin{tabular}{|c|c|c|c|c|c|c|}
\hline $\begin{array}{l}\text { Dependent variable: } \\
\ln \text { (real exports) }\end{array}$ & $(1)$ & $(2)$ & $(3)$ & $(4)$ & $(5)$ & $(6)$ \\
\hline Financial crisis & $\begin{array}{l}0.018 \\
(0.067)\end{array}$ & $\begin{array}{l}0.067 \\
(0.068)\end{array}$ & $\begin{array}{l}0.069 \\
(0.068)\end{array}$ & $\begin{array}{l}0.025 \\
(0.066)\end{array}$ & $\begin{array}{l}0.057 \\
(0.066)\end{array}$ & $\begin{array}{l}0.062 \\
(0.066)\end{array}$ \\
\hline US real interest rate & $\begin{array}{l}-0.024 \\
(0.015)\end{array}$ & $\begin{array}{l}-0.014 \\
(0.015)\end{array}$ & $\begin{array}{l}-0.015 \\
(0.015)\end{array}$ & $\begin{array}{l}-0.022 \\
(0.015)\end{array}$ & $\begin{array}{l}-0.026^{*} \\
(0.015)\end{array}$ & $\begin{array}{l}-0.028^{*} \\
(0.015)\end{array}$ \\
\hline Expected $\Delta \ln (\mathrm{RER})$ & $\begin{array}{l}0.011 \\
(0.008)\end{array}$ & $\begin{array}{l}0.012 \\
(0.008)\end{array}$ & $\begin{array}{l}0.010 \\
(0.008)\end{array}$ & $\begin{array}{l}0.011 \\
(0.008)\end{array}$ & $\begin{array}{l}0.009 \\
(0.008)\end{array}$ & $\begin{array}{l}0.007 \\
(0.008)\end{array}$ \\
\hline Country credit risk & $\begin{array}{l}-0.003 \\
(0.007)\end{array}$ & $\begin{array}{l}-0.007 \\
(0.007)\end{array}$ & $\begin{array}{l}-0.009 \\
(0.007)\end{array}$ & $\begin{array}{l}-0.005 \\
(0.007)\end{array}$ & $\begin{array}{l}-0.007 \\
(0.007)\end{array}$ & $\begin{array}{l}-0.008 \\
(0.007)\end{array}$ \\
\hline $\begin{array}{l}\text { Unexpected } \Delta \ln (\text { RER }) \\
\mathrm{x} \ln (\operatorname{RIIM}(-1))\end{array}$ & $\begin{array}{l}-0.0002^{* * *} \\
(0.000)\end{array}$ & $\begin{array}{l}-0.0003^{* * *} \\
(0.000)\end{array}$ & $\begin{array}{l}-0.0003^{* * *} \\
(0.000)\end{array}$ & & & \\
\hline $\begin{array}{l}\text { Unexpected } \Delta \ln (\text { RER }) \\
\mathrm{x} \ln (\operatorname{RDEBT}(-2))\end{array}$ & & & & $\begin{array}{l}-0.0003^{* * *} \\
(0.000)\end{array}$ & $\begin{array}{l}-0.0003^{* * *} \\
(0.000)\end{array}$ & $\begin{array}{l}-0.0003^{* * *} \\
(0.000)\end{array}$ \\
\hline Debt to sales(-2) & $\begin{array}{l}-0.002^{* * *} \\
(0.001)\end{array}$ & & & $\begin{array}{l}-0.002^{* * *} \\
(0.001)\end{array}$ & & \\
\hline Cash flow to sales $(-1)$ & & $\begin{array}{l}0.005^{* * *} \\
(0.002)\end{array}$ & & & $\begin{array}{l}0.006^{* * *} \\
(0.002)\end{array}$ & \\
\hline Trade credit to sales $(-1)$ & & & $\begin{array}{l}0.005^{* * *} \\
(0.002)\end{array}$ & & & $\begin{array}{l}0.006^{* * *} \\
(0.002)\end{array}$ \\
\hline $\ln (\mathrm{XRER})$ & $\begin{array}{l}0.452^{* *} \\
(0.220)\end{array}$ & $\begin{array}{l}0.489 * * \\
(0.219)\end{array}$ & $\begin{array}{l}0.580^{* * *} \\
(0.217)\end{array}$ & $\begin{array}{l}0.485^{* *} \\
(0.219)\end{array}$ & $\begin{array}{l}0.482^{* *} \\
(0.220)\end{array}$ & $\begin{array}{l}0.597^{* * *} \\
(0.216)\end{array}$ \\
\hline $\ln (\mathrm{MRER})$ & $\begin{array}{l}-0.989^{* * *} \\
(0.214)\end{array}$ & $\begin{array}{l}-1.111^{* * *} \\
(0.226)\end{array}$ & $\begin{array}{l}-1.063^{* * *} \\
(0.227)\end{array}$ & $\begin{array}{l}-0.968^{* * *} \\
(0.215)\end{array}$ & $\begin{array}{l}-1.154^{* * *} \\
(0.208)\end{array}$ & $\begin{array}{l}-1.104^{* * *} \\
(0.209)\end{array}$ \\
\hline $\ln (\mathrm{RGDP})$ & $\begin{array}{l}1.296^{* * *} \\
(0.207)\end{array}$ & $\begin{array}{l}1.515^{* * *} \\
(0.210)\end{array}$ & $\begin{array}{l}1.428^{* * *} \\
(0.207)\end{array}$ & $\begin{array}{l}1.273^{* * *} \\
(0.206)\end{array}$ & $\begin{array}{l}1.319^{* * *} \\
(0.206)\end{array}$ & $\begin{array}{l}1.205^{* * *} \\
(0.201)\end{array}$ \\
\hline $\ln ($ real wage $)$ & $\begin{array}{l}-0.453^{* * *} \\
(0.063)\end{array}$ & $\begin{array}{l}-0.444^{* * *} \\
(0.059)\end{array}$ & $\begin{array}{l}-0.445^{* * *} \\
(0.058)\end{array}$ & $\begin{array}{l}-0.454^{* * *} \\
(0.063)\end{array}$ & $\begin{array}{l}-0.424^{* * *} \\
(0.060)\end{array}$ & $\begin{array}{l}-0.425^{* * *} \\
(0.060)\end{array}$ \\
\hline $\ln (\mathrm{TFP})$ & $\begin{array}{l}0.868^{* * *} \\
(0.078)\end{array}$ & $\begin{array}{l}0.868^{* * *} \\
(0.079)\end{array}$ & $\begin{array}{l}0.881^{* * *} \\
(0.079)\end{array}$ & $\begin{array}{l}0.868^{* * *} \\
(0.078)\end{array}$ & $\begin{array}{l}0.878^{* * *} \\
(0.080)\end{array}$ & $\begin{array}{l}0.889^{* * *} \\
(0.081)\end{array}$ \\
\hline $\ln ($ distance $)$ & $\begin{array}{l}-0.183^{* *} \\
(0.0843)\end{array}$ & $\begin{array}{l}-0.243^{* * *} \\
(0.088)\end{array}$ & $\begin{array}{l}-0.239^{* * *} \\
(0.088)\end{array}$ & $\begin{array}{l}-0.181^{* *} \\
(0.084)\end{array}$ & $\begin{array}{l}-0.177^{* *} \\
(0.084)\end{array}$ & $\begin{array}{l}-0.182^{* *} \\
(0.084)\end{array}$ \\
\hline Constant & $\begin{array}{l}15.24^{* * *} \\
(1.206)\end{array}$ & $\begin{array}{l}14.77^{* * * *} \\
(1.284)\end{array}$ & $\begin{array}{l}14.54^{* * *} \\
(1.276)\end{array}$ & $\begin{array}{l}15.08^{* * *} \\
(1.205)\end{array}$ & $\begin{array}{l}15.42^{* * *} \\
(1.185)\end{array}$ & $\begin{array}{l}15.27^{* * *} \\
(1.179)\end{array}$ \\
\hline Sample size & 4,261 & 4,640 & 4,645 & 4,261 & 4,175 & 4,179 \\
\hline$R^{2}$ & 0.897 & 0.882 & 0.882 & 0.897 & 0.897 & 0.897 \\
\hline Firm FE & Yes & Yes & Yes & Yes & Yes & Yes \\
\hline Sector FE & Yes & Yes & Yes & Yes & Yes & Yes \\
\hline
\end{tabular}

Note: The financial crisis dummy is 1 for the years 1997, 1998, 2008 and 2009, and 0 for other years.

The unit of real interest rate, real exchange rate depreciation, debt to sales, cash flow to sales and trade credit to sales is $\%$. FE denotes fixed effects. Robust standard errors are in parentheses. $* * *, * *$ and $*$ denote $1 \%, 5 \%$ and $10 \%$ significance level, respectively. 
Other estimated coefficients are quite similar to the baseline results in Table 4. In Table 6, we extend the definition of crisis years to two-year periods, namely 1997-1998 and 2008-2009. In this case, the estimated coefficients of the financial crisis dummy is not significant either. These results indicate that our determinants of firm-level real interest rate have captured the effects of financial crises.

\subsection{Robustness Check}

We perform two robustness checks in this subsection. First, we use an alternative inputoutput coefficient. Specifically, for each pair of input $s^{\prime}$ and output $s$ and for all time $t$, we employ $a_{s s^{\prime} t}=\overline{a_{s s^{\prime}}}$, or the average of input-output coefficients over all years in which data are available. Let MRER2 denote the import-share weighted multilateral RER based on this new input-output coefficient. The estimation results in Table 7 are quite similar to those in Table 4 both in terms of size and statistical significance. This implies that our baseline results are not sensitive to the choice of input-output coefficients.

Second, we use a sub-sample, which is a balanced panel. In this sub-sample, all firms are continuous exporters throughout the sample period. In Table 8, the estimated coefficients of the unexpected RER depreciation interacting with lagged RIIM or lagged debt, the XRER and the MRER have the expected signs and are statistically significant. Overall, a depreciation has a contractionary effect on exports across all specifications. The US real interest rate, country's credit risk and expected RER depreciation continue to be statistically not different from zero. However, the ratio of trade credit to sales is the only proxy for the firm-level risk not associated to currency risk that is statistically significant. These results imply that our baseline results 
Table 7: Determinants of firm-level real exports - Alternative measure of import-share weighted RER

\begin{tabular}{|c|c|c|c|c|c|c|}
\hline $\begin{array}{l}\text { Dependent variable: } \\
\ln \text { (real exports) }\end{array}$ & $(1)$ & $(2)$ & $(3)$ & $(4)$ & $(5)$ & $(6)$ \\
\hline US real interest rate & $\begin{array}{l}-0.022 \\
(0.015)\end{array}$ & $\begin{array}{l}-0.010 \\
(0.015)\end{array}$ & $\begin{array}{l}-0.011 \\
(0.015)\end{array}$ & $\begin{array}{l}-0.020 \\
(0.015)\end{array}$ & $\begin{array}{l}-0.022 \\
(0.015)\end{array}$ & $\begin{array}{l}-0.024 \\
(0.015)\end{array}$ \\
\hline Expected $\Delta \ln (\mathrm{RER})$ & $\begin{array}{l}0.010 \\
(0.007)\end{array}$ & $\begin{array}{l}0.008 \\
(0.007)\end{array}$ & $\begin{array}{l}0.006 \\
(0.007)\end{array}$ & $\begin{array}{l}0.009 \\
(0.007)\end{array}$ & $\begin{array}{l}0.005 \\
(0.007)\end{array}$ & $\begin{array}{l}0.004 \\
(0.007)\end{array}$ \\
\hline Country credit risk & $\begin{array}{l}-0.003 \\
(0.006)\end{array}$ & $\begin{array}{l}-0.004 \\
(0.006)\end{array}$ & $\begin{array}{l}-0.006 \\
(0.006)\end{array}$ & $\begin{array}{l}-0.004 \\
(0.006)\end{array}$ & $\begin{array}{l}-0.004 \\
(0.006)\end{array}$ & $\begin{array}{l}-0.006 \\
(0.006)\end{array}$ \\
\hline $\begin{array}{l}\text { Unexpected } \Delta \ln (\text { RER }) \\
\mathrm{x} \ln (\operatorname{RIIM}(-1))\end{array}$ & $\begin{array}{l}-0.0002^{* * *} \\
(0.000)\end{array}$ & $\begin{array}{l}-0.0003^{* * *} \\
(0.000)\end{array}$ & $\begin{array}{l}-0.0003^{* * *} \\
(0.000)\end{array}$ & & & \\
\hline $\begin{array}{l}\text { Unexpected } \Delta \ln (\text { RER }) \\
\mathrm{x} \ln (\operatorname{RDEBT}(-2))\end{array}$ & & & & $\begin{array}{l}-0.0003^{* * *} \\
(0.000)\end{array}$ & $\begin{array}{l}-0.0003^{* * *} \\
(0.000)\end{array}$ & $\begin{array}{l}-0.0003^{* * *} \\
(0.000)\end{array}$ \\
\hline Debt to sales $(-2)$ & $\begin{array}{l}-0.002^{* * *} \\
(0.001)\end{array}$ & & & $\begin{array}{l}-0.002^{* * *} \\
(0.001)\end{array}$ & & \\
\hline Cash flow to sales $(-1)$ & & $\begin{array}{l}0.005^{* * *} \\
(0.002)\end{array}$ & & & $\begin{array}{l}0.006^{* * *} \\
(0.002)\end{array}$ & \\
\hline Trade credit to sales $(-1)$ & & & $\begin{array}{l}0.005^{* * *} \\
(0.002)\end{array}$ & & & $\begin{array}{l}0.006^{* * *} \\
(0.002)\end{array}$ \\
\hline $\ln (\mathrm{XRER})$ & $\begin{array}{l}0.461^{* *} \\
(0.201)\end{array}$ & $\begin{array}{l}0.438 * * \\
(0.202)\end{array}$ & $\begin{array}{l}0.526^{* * *} \\
(0.200)\end{array}$ & $\begin{array}{l}0.485^{* *} \\
(0.200)\end{array}$ & $\begin{array}{l}0.444^{* *} \\
(0.202)\end{array}$ & $\begin{array}{l}0.550^{* * *} \\
(0.199)\end{array}$ \\
\hline $\ln ($ MRER2) & $\begin{array}{l}-0.970^{* * *} \\
(0.212)\end{array}$ & $\begin{array}{l}-1.063^{* * *} \\
(0.219)\end{array}$ & $\begin{array}{l}-1.014^{* * *} \\
(0.221)\end{array}$ & $\begin{array}{l}-0.948^{* * *} \\
(0.214)\end{array}$ & $\begin{array}{l}-1.100^{* * *} \\
(0.208)\end{array}$ & $\begin{array}{l}-1.048^{* * *} \\
(0.209)\end{array}$ \\
\hline $\ln (\mathrm{RGDP})$ & $\begin{array}{l}1.318^{* * *} \\
(0.159)\end{array}$ & $\begin{array}{l}1.625^{* * *} \\
(0.161)\end{array}$ & $\begin{array}{l}1.542^{* * *} \\
(0.158)\end{array}$ & $\begin{array}{l}1.308^{* * *} \\
(0.160)\end{array}$ & $\begin{array}{l}1.410^{* * *} \\
(0.159)\end{array}$ & $\begin{array}{l}1.306^{* * *} \\
(0.155)\end{array}$ \\
\hline $\ln ($ real wage $)$ & $\begin{array}{l}-0.452^{* * *} \\
(0.062)\end{array}$ & $\begin{array}{l}-0.441^{* * *} \\
(0.058)\end{array}$ & $\begin{array}{l}-0.442^{* * *} \\
(0.058)\end{array}$ & $\begin{array}{l}-0.453^{* * *} \\
(0.063)\end{array}$ & $\begin{array}{l}-0.422^{* * *} \\
(0.060)\end{array}$ & $\begin{array}{l}-0.422^{* * *} \\
(0.060)\end{array}$ \\
\hline $\ln (\mathrm{TFP})$ & $\begin{array}{l}0.869^{* * *} \\
(0.078)\end{array}$ & $\begin{array}{l}0.867^{* * *} \\
(0.079)\end{array}$ & $\begin{array}{l}0.880^{* * *} \\
(0.079)\end{array}$ & $\begin{array}{l}0.868^{* * *} \\
(0.078)\end{array}$ & $\begin{array}{l}0.877^{* * *} \\
(0.080)\end{array}$ & $\begin{array}{l}0.888^{* * *} \\
(0.080)\end{array}$ \\
\hline $\ln ($ distance $)$ & $\begin{array}{l}-0.186^{* *} \\
(0.084)\end{array}$ & $\begin{array}{l}-0.252^{* * *} \\
(0.088)\end{array}$ & $\begin{array}{l}-0.248^{* * *} \\
(0.088)\end{array}$ & $\begin{array}{l}-0.185^{* *} \\
(0.084)\end{array}$ & $\begin{array}{l}-0.186^{* *} \\
(0.084)\end{array}$ & $\begin{array}{l}-0.191^{* *} \\
(0.084)\end{array}$ \\
\hline Constant & $\begin{array}{l}15.03^{* * *} \\
(1.167)\end{array}$ & $\begin{array}{l}14.34^{* * *} \\
(1.220)\end{array}$ & $\begin{array}{l}14.11^{* * *} \\
(1.212)\end{array}$ & $\begin{array}{l}14.86^{* * *} \\
(1.165)\end{array}$ & $\begin{array}{l}14.99^{* * *} \\
(1.148)\end{array}$ & $\begin{array}{l}14.83^{* * *} \\
(1.141)\end{array}$ \\
\hline Sample size & 4,261 & 4,640 & 4,645 & 4,261 & 4,175 & 4,179 \\
\hline$R^{2}$ & 0.897 & 0.882 & 0.882 & 0.897 & 0.897 & 0.897 \\
\hline Firm FE & Yes & Yes & Yes & Yes & Yes & Yes \\
\hline Sector FE & Yes & Yes & Yes & Yes & Yes & Yes \\
\hline
\end{tabular}

Note: The unit of real interest rate, RER depreciation, debt to sales, cash flow to sales and trade credit to sales is \%. FE denotes fixed effects. Robust standard errors are in parentheses. $* * *, * *$ and $*$ denote $1 \%, 5 \%$ and $10 \%$ significance level, respectively. 
Table 8: Determinants of firm-level real exports - Balanced panel

\begin{tabular}{|c|c|c|c|c|c|c|}
\hline $\begin{array}{l}\text { Dependent variable: } \\
\ln \text { (real exports) }\end{array}$ & $(1)$ & $(2)$ & $(3)$ & $(4)$ & $(5)$ & $(6)$ \\
\hline US real interest rate & $\begin{array}{l}-0.027 \\
(0.019)\end{array}$ & $\begin{array}{l}-0.009 \\
(0.019)\end{array}$ & $\begin{array}{l}-0.008 \\
(0.019)\end{array}$ & $\begin{array}{l}-0.025 \\
(0.020)\end{array}$ & $\begin{array}{l}-0.021 \\
(0.019)\end{array}$ & $\begin{array}{l}-0.020 \\
(0.019)\end{array}$ \\
\hline Expected $\Delta \ln (\mathrm{RER})$ & $\begin{array}{l}-0.002 \\
(0.009)\end{array}$ & $\begin{array}{l}0.001 \\
(0.008)\end{array}$ & $\begin{array}{c}-0.0004 \\
(0.008)\end{array}$ & $\begin{array}{l}-0.002 \\
(0.009)\end{array}$ & $\begin{array}{l}0.0001 \\
(0.008)\end{array}$ & $\begin{array}{l}-0.001 \\
(0.008)\end{array}$ \\
\hline Country credit risk & $\begin{array}{l}-0.008 \\
(0.008)\end{array}$ & $\begin{array}{l}-0.009 \\
(0.008)\end{array}$ & $\begin{array}{l}-0.008 \\
(0.007)\end{array}$ & $\begin{array}{l}-0.009 \\
(0.008)\end{array}$ & $\begin{array}{l}-0.005 \\
(0.007)\end{array}$ & $\begin{array}{l}-0.005 \\
(0.007)\end{array}$ \\
\hline $\begin{array}{l}\text { Unexpected } \Delta \ln (\text { RER }) \\
\mathrm{x} \ln (\operatorname{RIIM}(-1))\end{array}$ & $\begin{array}{l}-0.0002^{* * *} \\
(0.000)\end{array}$ & $\begin{array}{l}-0.0003^{* * *} \\
(0.000)\end{array}$ & $\begin{array}{l}-0.0003^{* * *} \\
(0.000)\end{array}$ & & & \\
\hline $\begin{array}{l}\text { Unexpected } \Delta \ln (\mathrm{RER}) \\
\mathrm{x} \ln (\operatorname{RDEBT}(-2))\end{array}$ & & & & $\begin{array}{l}-0.0003^{* * *} \\
(0.000)\end{array}$ & $\begin{array}{l}-0.0003^{* * *} \\
(0.000)\end{array}$ & $\begin{array}{l}-0.0003^{* * *} \\
(0.000)\end{array}$ \\
\hline Debt to sales(-2) & $\begin{array}{l}-0.001 \\
(0.001)\end{array}$ & & & $\begin{array}{l}-0.001 \\
(0.001)\end{array}$ & & \\
\hline Cash flow to sales $(-1)$ & & $\begin{array}{l}0.0003 \\
(0.002)\end{array}$ & & & $\begin{array}{l}0.001 \\
(0.002)\end{array}$ & \\
\hline Trade credit to sales $(-1)$ & & & $\begin{array}{l}0.005^{*} \\
(0.003)\end{array}$ & & & $\begin{array}{l}0.004^{*} \\
(0.003)\end{array}$ \\
\hline $\ln (\mathrm{XRER})$ & $\begin{array}{l}1.244^{* * *} \\
(0.288)\end{array}$ & $\begin{array}{l}1.058^{* * *} \\
(0.259)\end{array}$ & $\begin{array}{l}1.066^{* * *} \\
(0.256)\end{array}$ & $\begin{array}{l}1.254^{* * *} \\
(0.287)\end{array}$ & $\begin{array}{l}1.065^{* * *} \\
(0.256)\end{array}$ & $\begin{array}{l}1.085^{* * *} \\
(0.251)\end{array}$ \\
\hline $\ln (\mathrm{MRER})$ & $\begin{array}{l}-1.545^{* * *} \\
(0.285)\end{array}$ & $\begin{array}{l}-1.410^{* * *} \\
(0.307)\end{array}$ & $\begin{array}{l}-1.342^{* * *} \\
(0.310)\end{array}$ & $\begin{array}{l}-1.537^{* * *} \\
(0.290)\end{array}$ & $\begin{array}{l}-1.647^{* * * *} \\
(0.279)\end{array}$ & $\begin{array}{l}-1.593^{* * *} \\
(0.281)\end{array}$ \\
\hline $\ln (\mathrm{RGDP})$ & $\begin{array}{l}0.925^{* * *} \\
(0.229)\end{array}$ & $\begin{array}{l}1.255^{* * *} \\
(0.189)\end{array}$ & $\begin{array}{l}1.218^{* * *} \\
(0.187)\end{array}$ & $\begin{array}{l}0.922^{* * *} \\
(0.230)\end{array}$ & $\begin{array}{l}1.100^{* * *} \\
(0.180)\end{array}$ & $\begin{array}{l}1.055^{* * *} \\
(0.177)\end{array}$ \\
\hline $\ln$ (real wage) & $\begin{array}{l}-0.274^{* * *} \\
(0.087)\end{array}$ & $\begin{array}{l}-0.309^{* * *} \\
(0.087)\end{array}$ & $\begin{array}{l}-0.299^{* * *} \\
(0.086)\end{array}$ & $\begin{array}{l}-0.275^{* * *} \\
(0.087)\end{array}$ & $\begin{array}{l}-0.277^{* * *} \\
(0.088)\end{array}$ & $\begin{array}{l}-0.270^{* * *} \\
(0.088)\end{array}$ \\
\hline $\ln (\mathrm{TFP})$ & $\begin{array}{l}0.957^{* * *} \\
(0.102)\end{array}$ & $\begin{array}{l}0.918^{* * *} \\
(0.102)\end{array}$ & $\begin{array}{l}0.902^{* * *} \\
(0.105)\end{array}$ & $\begin{array}{l}0.955^{* * *} \\
(0.102)\end{array}$ & $\begin{array}{l}0.912^{* * *} \\
(0.099)\end{array}$ & $\begin{array}{l}0.905^{* * *} \\
(0.103)\end{array}$ \\
\hline $\ln ($ distance $)$ & $\begin{array}{l}-0.292^{* * *} \\
(0.103)\end{array}$ & $\begin{array}{l}-0.386^{* * *} \\
(0.108)\end{array}$ & $\begin{array}{l}-0.385^{* * *} \\
(0.107)\end{array}$ & $\begin{array}{l}-0.293^{* * *} \\
(0.103)\end{array}$ & $\begin{array}{l}-0.324^{* * *} \\
(0.104)\end{array}$ & $\begin{array}{l}-0.326^{* * *} \\
(0.103)\end{array}$ \\
\hline Constant & $\begin{array}{l}16.03^{* * *} \\
(1.554)\end{array}$ & $\begin{array}{l}15.43^{* * *} \\
(1.592)\end{array}$ & $\begin{array}{l}15.19^{* * *} \\
(1.583)\end{array}$ & $\begin{array}{l}15.97^{* * *} \\
(1.564)\end{array}$ & $\begin{array}{l}16.72^{* * *} \\
(1.514)\end{array}$ & $\begin{array}{l}16.56^{* * *} \\
(1.501)\end{array}$ \\
\hline Sample size & 1,846 & 1,958 & 1,961 & 1,846 & 1,830 & 1,833 \\
\hline$R^{2}$ & 0.905 & 0.891 & 0.891 & 0.905 & 0.910 & 0.910 \\
\hline Firm FE & Yes & Yes & Yes & Yes & Yes & Yes \\
\hline Sector FE & Yes & Yes & Yes & Yes & Yes & Yes \\
\hline
\end{tabular}

Note: The unit of real interest rate, RER depreciation, debt to sales, cash flow to sales and trade credit to sales is \%. FE denotes fixed effects. Robust standard errors are in parentheses. $* * *, * *$ and * denote $1 \%, 5 \%$ and $10 \%$ significance level, respectively. 
hold regardless of balanced or unbalanced data.

\section{Conclusion}

Our study incorporates intermediate inputs into a trade model in order to examine the impacts of currency depreciation on firm-level costs of borrowing and exports. We differentiate the effects of currency depreciation by three channels through which it influences exports: financing costs or the balance sheet effect; costs of intermediate inputs; and price competitiveness. The main idea is that purchases of intermediate inputs are financed by borrowing from domestic lenders or foreign lenders or both. Then, we demonstrate that the measures of exchange rates for each channel are different and crucially depend on the extent of financing, the input-output structure, and the structure of trade in goods markets.

Specifically, our measures of exchange rates for each channel are the interaction of unexpected RER depreciation with the lagged real value of imported intermediate inputs, the import-share weighted multilateral RER, and the export-share weighted multilateral RER, respectively. We predict that an unexpected RER depreciation has negative effects on exports through the first and the second channels, and a positive effect through the last channel.

In the empirical part, we construct firm-level real interest rates and employ a panel of the Korean firm's exports, wages, sector-level multilateral RERs and TFP, Korea-US RER, and typical control variables such as the income of the destination countries and distance. Then, we exploit cross-firm variations in costs, cross-sector variations in multilateral RERs and timeseries variation in all variables, controlling for firm fixed effects and sector fixed effects. Our results strongly support the predictions. 
We make the following contributions to the literature. First, we find that a rise in the firmlevel interest rate, as a result of increases in currency risk, credit risk and liquidity risk, has detrimental effects on exports. Our findings lend support to the literature on contractionary devaluations and identify the channels through which contractionary devaluations occur. The existing studies such as Cespedes et al. (2004) and Kim et al. (2012) emphasize the balance sheet effect as the cause of contractionary devaluation. On the other hand, in our case, contractionary devaluations occur even if we do not take into account the balance sheet effect because we incorporate the impact of devaluations on the costs of intermediate inputs into our estimation. Hence, even if foreign debts are all local currency debts, devaluations will still be contractionary as long as the prices of intermediate inputs are not sticky in local currency.

Second, we provide direct evidence for the balance sheet effect of unexpected RER depreciation on the firm-level real interest rate, controlling for the impacts of country-level risk and firm-level risk. Our estimates suggest that a $1 \%$ unexpected RER depreciation and one standard deviation increase in lagged imports of intermediate inputs would raise the firm-level real interest rate by $0.195 \%$. Given the actual $60 \%$ won-dollar RER depreciation rate in 1997, the implied balance sheet effect of the won crisis could increase the real interest rate for firms of which lagged imports of intermediate inputs is one standard deviation higher than other firms in 1997 by as much as $11.70 \%$. This balance sheet effect is substantial.

Finally, our work is in line with Besedes et al. (2014) and Chor and Manova (2012), who use the country-level interbank lending rate multiplied with the sector-specific and time invariant degree of external finance as a proxy for the sector-specific interest rate and estimate its impact on exports. However, their degree of external finance dependence is the fraction of capital 
expenditures not financed by internal cash flows from operations, as in Rajan and Zingales (1998). Hence, their concept of external finance is much broader than debt financing and their financing costs are not necessarily sector-level interest rates. It is difficult to compare the magnitude of our estimates with those found in the existing studies, because none of them use an explicit measure of the firm-level real interest rate. In addition, although Feenstra et al. (2014) find that the firm-specific interest payment has a negative and significant impact on sales, they neither account for currency risk nor examine determinants of the firm-level real interest rate.

One caveat in our study is that we assume that the set of destination countries for exports and the source countries for imported intermediate inputs are exogenous. In the data, these sets vary over time, and we do not take a stand about their determinants. In Amiti et al. (2014), the choice of source countries is endogenous, whereas the set of exporting destinations is exogenous. In our case, the source-specific prices of imports are not observed, and thus we have no data to test any hypothesis related to the choice of source countries. For this reason, we refrain from modeling the choice of source countries. 


\section{Appendix}

\section{A Derivation of Equilibrium Exports}

Substituting supply in equation (4) into demand in equation (3), multiplying it with the export share $\omega_{j s}$ and then aggregating over destination country $j$ yields the sum of the logarithm of firm-level exports from country $i$ :

$$
\begin{aligned}
\sum_{j} \omega_{j s} \ln X_{f s i j}= & -\theta \sum_{j} \omega_{j s} \mu_{s i}-\theta \sum_{j} \omega_{j s} \alpha_{s i} \ln \left(R_{f i}\right)-\theta \delta_{s i} \sum_{j} \omega_{j s} \sum_{k} \omega_{k s}\left[\ln \left(E_{i k}\right)+\ln \left(p_{s i k}^{\star m}\right)\right] \\
& +\theta \sum_{j} \omega_{j s}\left[\ln \left(E_{i j}\right)+\ln \left(P_{j}\right)\right]-\theta \sum_{j} \omega_{j s}\left(1-\alpha_{s i}-\delta_{s i}\right) \ln \left(W_{f i}\right) \\
& +\theta \sum_{j} \omega_{j s} \ln \left(A_{s i}\right)+\sum_{j} \omega_{j s} \ln \left(Y_{j}\right)
\end{aligned}
$$

Next, we rewrite (A.1) using the definitions of MRERs, XRERs, RERs, the real interest rate and the real wage:

$$
\begin{aligned}
\sum_{j}^{N_{x}} \omega_{j s} \ln X_{f s i j}= & -\theta \mu_{s i}-\theta \alpha_{s i} r_{f i}-\theta \delta_{s i} \ln \left(M R E R_{s i}\right)+\theta \ln \left(X R E R_{s i}\right) \\
& -\theta \delta_{s i} \sum_{k}^{N_{m}} \omega_{s k}\left(\ln \left(p_{s i k}^{\star m}\right)-\ln \left(P_{k}\right)\right)-\theta\left(1-\alpha_{s i}-\delta_{s i}\right) \ln \left(w_{f i}\right) \\
& +\theta \ln \left(A_{s i}\right)+\ln \left(R G D P_{s i}\right)
\end{aligned}
$$

Although $\sum_{j}^{N_{x}} \ln X_{f s i j} \neq \ln \left(\sum_{j}^{N_{x}} X_{f s i j}\right)$, we can approximate $\ln \left(\sum_{j}^{N_{x}} X_{f s i j}\right)$ using the Taylor expansion around $\Pi_{j}^{N_{x}} X_{f s i j}^{\omega_{j s}}$ :

$$
\ln \left(\sum_{j}^{N_{x}} X_{f s i j}\right)=\sum_{j}^{N_{x}} \omega_{j s} \ln X_{f s i j}+\left(\frac{\sum_{j}^{N_{x}} X_{f s i j}}{\Pi_{j}^{N_{x}} X_{f s i j}}-1\right)
$$

The second term on the right-hand-side is the discrepancy from approximation. It depends on the dispersion of exports across destinations. In the extreme case, when exports to all 
destinations are identical, the discrepancy is zero.

Define $X_{f s i}=\sum_{j}^{N_{x}} X_{f s i j}$. Finally, substituting (A.3) into (A.2) and applying the definition of $X_{f s i}$ yields the total exports of firm $f$ in sector $s$ in country $i$ in logarithm:

$$
\begin{aligned}
\ln \left(X_{f s i}\right)= & -\theta \mu_{s i}-\theta \alpha_{s i} r_{f i}-\theta \delta_{s i} \ln \left(\operatorname{MRER}_{s i}\right)+\theta \ln \left(X R E R_{s i}\right) \\
& -\theta \delta_{s i} \sum_{k}^{N_{m}} \omega_{s k}\left(\ln \left(p_{s i k}^{\star m}\right)-\ln \left(P_{k}\right)\right)-\theta\left(1-\alpha_{s i}-\delta_{s i}\right) \ln \left(w_{f i}\right) \\
& +\theta \ln \left(A_{s i}\right)+\ln \left(R G D P_{s i}\right)-\left(\frac{X_{f s i}}{\Pi_{j}^{N_{x}} X_{f s i j}}-1\right)
\end{aligned}
$$

\section{B Measuring Total Factor Productivity}

Assume production function has the Cobb-Douglas form: $Y_{f s t}=A_{f s t} K_{f s t}^{\beta_{s k}} L_{f s t}^{\beta_{s l}} M_{f s t}^{\beta_{s m}}$ where $s$ denotes sector, $f$ denotes firm, and $t$ denotes time. $A_{f s t}$ is the Hicksian neutral efficiency level of firm $f$ in sector $s$ in at time $t$, and is unobservable to the researcher. Taking natural logs results in a linear production function:

$$
\ln (Y)_{f s t}=\beta_{0}+\beta_{s k} \ln \left(K_{f s t}\right)+\beta_{s l} \ln \left(L_{f s t}\right)+\beta_{s m} \ln \left(M_{f s t}\right)+\epsilon_{f s t}
$$

where $\beta_{0}+\epsilon_{f s t}=A_{f s t}$ and $\beta_{0}$ is mean efficiency level across sectors and over time. We use $Y_{f s t}$ is total sales $f_{s t} / P_{Y t}$, where $P_{Y t}$ is (nominal GDP/real GDP)x100. $K_{f s t}$ is (tangible assets $\left.f s t\right) / P_{K t}$ where $P_{K t}$ is (nominal gross fixed capital formation/real gross fixed capital formation)x100, $L_{f s t}$ is the number of employees of firm $f$ in sector $s$ at time t.

Since firm-level intermediate input information, $M_{s f t}$, is not available, alternatively we can use sector-level information or $M_{s t}$ from the input-output table. Still, the input-output table 
is not available for all sample years. For this reason, we use average of adjacent years to get intermediate inputs of missing years. Also, we include time fixed effect in the estimation to control for some variation of sector-level intermediate inputs. Then, we estimate equation (B.1) for each sector with ordinary least squares, exploiting variation across firms and across time, and obtain the total factor productivity as the sector-time specific residual. ${ }^{12}$

\section{References}

Aguiar, M. (2005). Investment, devaluation, and foreign currency exposure: The case of Mexico. Journal of Development Economics 78(1), 95-113.

Amiti, M., O. Itskhoki, and J. Koning (2014). Importers, exporters, and exchange rate disconnect. American Economic Review 104 (7), 1942-1978.

Amiti, M. and D. E. Weinstein (2011). Exports and financial shocks. Quarterly Journal of Economics 126(4), 1841-1877.

Anderson, J. E. and E. van Wincoop (2004). Trade costs. Journal of Economic Literature 42(3), 691-751.

Bems, R. and R. C. Johnson (2012). Value-added exchange rates. NBER Working Paper 18498 .

Besedes, T., B. Kim, and V. Lugovskyy (2014). Export growth and credit constraints. European Economic Review, forthcoming.

\footnotetext{
${ }^{12}$ In the total factor productivity literature, there are alternative semi-parametric estimator approaches, as in Olley and Pakes (1996), Levinsohn and Petrin (2003), and Ackerberg, Caves and Frazer (2006). However, this approach requires either the data on firm-level intermediate input usage or the data on firms' exits from the domestic market. Our data set does not meet these requirements.
} 
Bleakley, H. and K. Cowan (2008). Corporate dollar debt and depreciations: Much ado about nothing? The Review of Economics and Statistics 90(4), 612-626.

Borensztein, E. and J.-W. Lee (2002). Financial crisis and credit crunch in Korea: Evidence from firm-level data. Journal of Monetary Economics 49, 853-875.

Cespedes, L. J., R. Chang, and A. Velasco (2004). Balance sheets and exchange rate policy. American Economic Review 94(4), 1183-1193.

Chor, D. and K. Manova (2012). Off the cliff and back: Credit conditions and international trade during the global financial crisis. Journal of International Economics 87, 117-133.

Crucini, M. J., C. I. Telmer, and M. Zachariadis (2005). Understanding European real exchange rates. American Economic Review 95(3), 724-738.

Edwards, S. (1986). Are devaluations contractionary? Review of Economics and Statistics 68(3), 501-508.

Feenstra, R. C., Z. Li, and M. Yu (2014). Exports and credit constraints under incomplete information: Theory and evidence from China. The Review of Economics and Statistics, forthcoming.

Goldberg, L. S. (2004). Industry-specific exchange rates for the United States. Economic Policy Review 10(1).

Hackbarth, D., J. Miao, and E. Morellec (2006). Capital structure, credit risk, and macroeconomic conditions. Journal of Financial Economics 82, 519-550.

Hummels, D., J. Ishii, and K.-M. Yi (2001). The nature and growth of vertical specialization 
in world trade. Journal of International Economics 54(1), 75-96.

Kaminsky, G. L. and C. M. Reinhart (1999). The twin crises: The causes of banking and balance-of-payments problems. American Economic Review 89(3), 473-500.

Kesriyeli, M., E. Ozmen, and S. Yigita (2011). Corporate sector liability dollarization and exchange rate balance sheet effect in Turkey. Applied Economics 43, 4741-4747.

Lee, J.-W., Y. S. Lee, and B.-S. Lee (2000). The determination of corporate debt in Korea. Asian Economic Journal 14(4), 333-356.

Love, I., L. A. Preve, and V. Sarria-Allende (2007). Trade credit and bank credit: Evidence from recent financial crises. Journal of Financial Economics 83(2), 453-469.

Manova, K. (2013). Credit constraints, heterogeneous firms, and international trade. Review of Economic Studies 80, 711-744.

Melitz, M. J. (2003). The impact of trade on intra-industry reallocations and aggregate industry productivity. Econometrica 71(6), 1695-1725.

Morellec, E. (2001). Asset liquidity, capital structure, and secured debt. Journal of Financial Economics 61, 173-206.

Rajan, R. G. and L. Zingales (1998). Financial dependence and growth. American Economic Review 88(3), 559-586.

Trefler, D. and S. C. Zhu (2010). The structure of factor content predictions. Journal of International Economics 82(2), 195-207. 